\title{
ESTUDO DE PATOLOGIAS NOS SISTEMAS PREDIAIS HIDRÁULICOS E SANITÁRIOS DO PRÉDIO DO CICLO BÁSICO II DA UNICAMP
}

\author{
Paula de C. Teixeira', Ricardo P. A. Reis², Sérgio F. Gnipper ${ }^{3}$, Jorge V. F. Monteiro ${ }^{4}$ \\ Recebido em 25 de janeiro de 2011; recebido para revisão em 15 de março de 2011; aceito em 02 de maio de 2011; \\ disponivel on-line em 25 de julho de 2011
}

\section{PALAVRAS CHAVES}

Sistemas hidráulicos sanitários prediais;

Manutenção predial;

Patologias construtivas.

\begin{abstract}
RESUMO: Este trabalho apresenta o levantamento de patologias e não conformidades nos Sistemas Prediais Hidráulicos e Sanitários (SPHS) do prédio do Ciclo Básico II da Unicamp. Para a realização deste estudo foram utilizadas as metodologias de aplicação de Avaliação Pós Ocupação (APO) e Avaliação Durante Operação (ADO), com a intenção de mensurar a satisfação do usuário e o seu grau de percepção dessas patologias em associação com uma correspondente investigação técnica do desempenho dos sistemas. Foram aplicados 55 questionários a diferentes categorias de usuários, contendo quesitos ligados à caracterização do perfil do usuário, desempenho dos ambientes sanitários e satisfação de uso destes ambientes. Paralelamente foram investigadas patologias presentes nos ambientes por meio de avaliação in loco e registro fotográfico. Como resultados pode-se atribuir as principais patologias encontradas à falta de manutenção adequada e ao vandalismo. Pode-se notar também o grau de insatisfação de parte dos usuários quanto ao desempenho dos sistemas SPHS.
\end{abstract}

* Contato com os autores:

${ }^{1}$ e-mail : paulacteixeira@gmail.com (P.C.TEIXEIRA)

Mestranda em Engenharia Civil - FEC - Unicamp

${ }^{2}$ e-mail : rpareis@gmail.com (R.P.A.REIS)

Professor MSc. Universidade Federal de Goiás

${ }^{3}$ e-mail : gnipper@uol.com.br (S.F.GNIPPER)

Doutorando em Engenharia Civil - FEC - Unicamp

${ }^{4}$ e-mail : venaciocomgas@uol.com.br (J.V.F.Monteiro)

Doutorando em Engenharia Civil - FEC - Unicamp

ISSN: 2179-0612

(C) 2011 REEC - Todos os direitos reservados.

\section{INTRODUÇÃO}

Segundo Ilha (2009), são características inerentes aos Sistemas Prediais Hidráulicos e Sanitários (SPHS) a complexidade funcional intrínseca e a interrelação dinâmica dos seus diversos subsistemas, além da enorme variedade de materiais, componentes e equipamentos constituintes (tubos, conexões, registros, válvulas, acessórios, reservatórios, bombas, tanques, equipamentos de controle e medição, etc.). Tais peculiaridades podem dar origem a uma enorme diversidade de manifestações patológicas nas edificações. Estas vão desde falhas frequentes em certos equipamentos até intrincadas variações de grandezas hidráulicas, térmicas e pneumáticas associadas ao uso dos aparelhos sanitários.

Além disto, a partir do início de sua ocupação ou utilização, uma edificação fica sujeita ao processo natural e progressivo de obsolescência em seus sistemas prediais hidráulicos e sanitários originais, causado por múltiplos fatores. Entre estes constam manutenção deficiente ou irregular, falhas nos componentes, processos de desgaste ou envelhecimento natural dos materiais utilizados $e$ condições de exposição inadequadas. 
Ao longo da vida útil da edificação, portanto, os seus usuários se sujeitam, com maior ou menor frequência, às consequências das patologias que nelas surgem, destacadamente aquelas relacionadas aos SPHS. Em menor escala, os próprios usuários constituem fonte dessas patologias, seja por desinformação, por deficiência ou inexistência de manutenção, seja por uso inadequado dos aparelhos sanitários, que constituem o seu ponto de contato mais frequente com tais sistemas do edifício.

Em geral, patologias frequentes nos SPHS do edifício não envolvem sérios riscos à vida ou à saúde dos seus usuários. Porém, elas costumam causar transtornos, aborrecimentos e desconfortos, em geral associados aos sintomas comuns de suas manifestações. São exemplos vazamentos, ruídos ou obstruções frequentes em tubulações, mau cheiro e refluxos em sistemas prediais de esgoto sanitário e de águas pluviais, insuficiência de pressões e vazões nos aparelhos sanitários, oscilações na temperatura de utilização de água quente, entre outros. Poucas são as manifestações patológicas decorrentes do uso em termos relativos. A maior parte decorre de causas sistêmicas e de falhas de manutenção

Amorim (1989) ressalta que, depois de posta de colocada em uso uma edificação, os sistemas prediais hidráulicos e sanitários entram em equilíbrio com os seus usuários, sendo um dos subsistemas do edifício que com eles mais se relaciona, razão pela qual o seu mau funcionamento costuma causar-lhes problemas sérios ao bem estar físico e psicológico. Esta é a etapa onde menos pesquisas acontecem, mas cujos dados são de fundamental utilidade para a melhoria da qualidade (AMORIM e FUGAZZA, 1997).

Em suma, tem sido elevada a incidência de manifestações patológicas nos SPHS das edificações por múltiplas razões, entre as quais a grande diversidade característica de materiais e componentes, recentes avanços no setor ainda não suficientemente assimilados pelo meio técnico, grande complexidade funcional, eventuais riscos implícitos à saúde e à vida dos usuários, manutenção deficiente ou irregular, falhas nos componentes, processos de desgaste e envelhecimento natural dos materiais utilizados e condições de exposição inapropriadas.

\section{OBJETIVOS}

Este trabalho tem por finalidade apresentar os resultados de levantamento de patologias e não conformidades nos SPHS do prédio do Ciclo Básico II da Unicamp e da aplicação de questionários aos usuários de seus ambientes sanitários, com o objetivo de identificar as origens desses problemas e avaliar a percepção de patologias e a satisfação dos usuários.

\section{MATERIAL E MÉTODOS}

Para o desenvolvimento deste estudo, uma das metodologias empregadas para a avaliação dos SPHS da edificação foi à aplicação de um questionário, afixado em anexo, aos usuários que tinham acabado de utilizar os sanitários masculino e feminino do Ciclo Básico - II. O questionário foi aplicado em diferentes dias da semana e horários distintos. A intenção do método aplicado foi obter informações de pessoas que já haviam tido alguma experiência no uso dos ambientes sanitários do prédio, não somente dos alunos. A parte de avaliação dos funcionários, por sua vez, foi realizada com pessoas presentes nas salas do setor de manutenção e informática da edificação, localizadas próximas aos sanitários do pavimento térreo e, também, com um professor que acabara de utilizar o sanitário. A última amostra que participou do preenchimento do questionário foi obtida das funcionárias presentes na sala de atendimento da DAC Diretoria Acadêmica que utiliza ambientes sanitários diferenciados, exclusivos para funcionários.

Por meio da interpretação dos questionários aplicados procurou-se analisar a relação entre os usuários e os SPHS da edificação, avaliando o perfil de utilização, o desempenho do sistema e o conforto dos usuários.

Dentro da análise que relaciona o usuário aos aparelhos dos SPHS, foram estabelecidas duas frentes: a análise relacionada aos aparelhos no interior dos banheiros e a análise relativa ao aparelho externo existente, o bebedouro. Outro ponto levantado, já considerando o sistema predial como organismo que envelhece e merece manutenções constantes por "sofrer" com o tempo e uso, seria o quanto uma provável falta de manutenção afetaria o usuário. Neste sentido, além da avaliação in loco, foi utilizada a percepção do usuário para coleta de dados no diagnostico das patologias presentes na edificação. Por fim, outros subsistema do SPHS a serem analisados foram o de captação e condução das águas pluviais na edificação, o sistema de distribuição e suprimento de água e o sistema de combate à incêndio.

\section{RESULTADOS}

\subsection{Avaliação dos dados obtidos por meio da aplicação dos questionários}

Os dados coletados por meio da aplicação dos questionários foram tratados em separado, de acordo com a categoria da função dentro da edificação, sexo e população total. Os principais resultados são mostrados por meio de gráficos.

Ao todo foram preenchidos 55 questionários, entre 22 mulheres (40\% da amostra) e 33 homens (60\% da amostra). Da população masculina que contribuiu na pesquisa de opinião do usuário, 79\% eram alunos, $18 \%$ funcionários e $3 \%$ alunos externos. Já a população feminina foi assim caracterizada: $77 \%$ alunas, $14 \%$ funcionárias e $2 \%$ alunas externas.

No traçado do perfil do usuário, de acordo com a utilização dos aparelhos sanitários, foi levantada a frequência semanal de uso, em número de vezes em que o usuário utiliza cada aparelho, dentre estes, a bacia sanitária, o lavatório, o bebedouro, o 
mictório e o chuveiro. Como o chuveiro é utilizado apenas pelos funcionários, a amostra populacional caracterizada por alunos e visitantes externos não contempla resultados no uso deste aparelho. O aparelho mais utilizado pelos alunos foi o bebedouro, apresentando $43 \%$ com utilização quatro vezes na semana. Em segundo lugar vem o lavatório, seguido do mictório, conforme mostra o gráfico da Figura 1.

Muitos dos usuários ressaltaram que não utilizam o bebedouro devido a condições de higiene e não confiabilidade na qualidade da água.

De acordo com a eficiência dos ambientes sanitários, foi questionada a opinião do usuário com relação à distância e à quantidade de banheiros. Os questionários respondidos apontaram que 53,8\% dos usuários avaliados acham adequada a localização dos sanitários.

Os demais questionários indicaram indiferença ou insatisfação com a distância dos sanitários aos ambientes sanitários.
A maioria dos colaboradores também achou adequada a quantidade de sanitários $(63,5 \%)$, sendo que $21,2 \%$ opinaram que o número é insuficiente e $15,4 \%$ se mostraram indiferentes.

O grau de satisfação dos usuários com o ambiente sanitário, conforme mostra o gráfico da Figura 2, mostrou maior parte de insatisfação com higiene, conforto, odor e projeto. $\mathrm{O}$ acesso foi considerado bom pela maioria dos usuários. A privacidade foi um fator que se relatou, em maioria, dividida entre satisfatório e insatisfatório.

Já o grau de satisfação dos usuários em relação à quantidade de aparelhos sanitários para atendimento da demanda, mostrado pelo gráfico da Figura 3, indicou um resultado negativo no âmbito dos bebedouros. Os demais indicadores se mostraram satisfatórios pela maioria dos usuários e, os chuveiros indiferentes, por não ser um aparelho de uso da maioria do publico entrevistado.

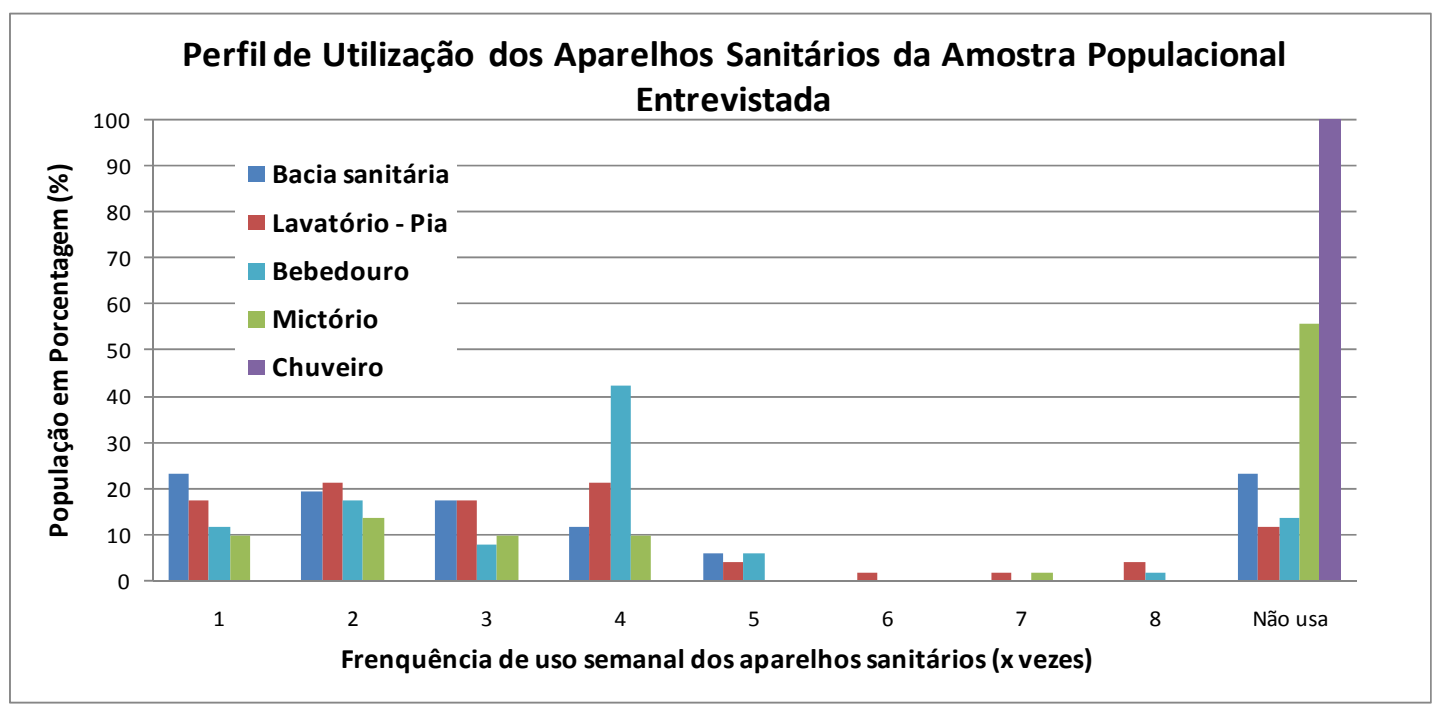

Figura 1: Perfil de utilização dos aparelhos sanitários da amostra populacional entrevistada.

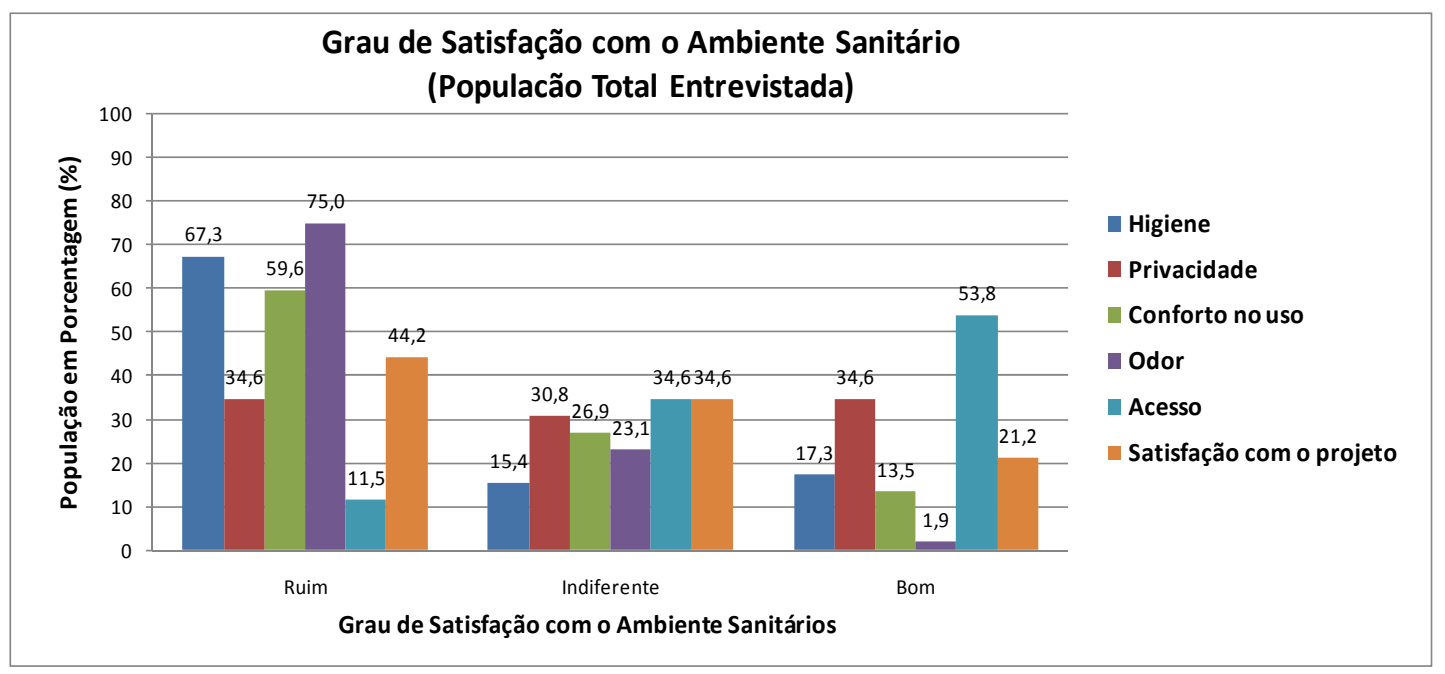

Figura 2: Grau de satisfação com o ambiente sanitário. 
Em busca de diagnosticar a percepção de patologias nos SPHS por parte dos usuários foram questionados pontos relativos ao desempenho de operação dos aparelhos e equipamentos. Os equipamentos avaliados foram: troneira (vazão) e válvula de descarga de bacias sanitárias e mictórios. Em relação ao funcionamento do sistema tentou-se detectar a percepção do usuário com relação à vibrações, incidência de vazamentos, entupimentos e disponibilidade de água. A maioria dos usuários relatou percepção com relação a vazamentos. Mostraram-se, também, indiferentes às vibrações e entupimentos e relataram um bom desempenho da válvula de descarga, na vazão das torneiras e disponibilidade de água.

Apesar da opinião geral, mostrada pelo gráfico da Figura 4, indicar um bom desempenho da descarga das bacias sanitárias, na opinião do público feminino este é indicado como um problema, assim como ruídos e vibrações, classificado por $63,2 \%$ dos questionários como ruim.

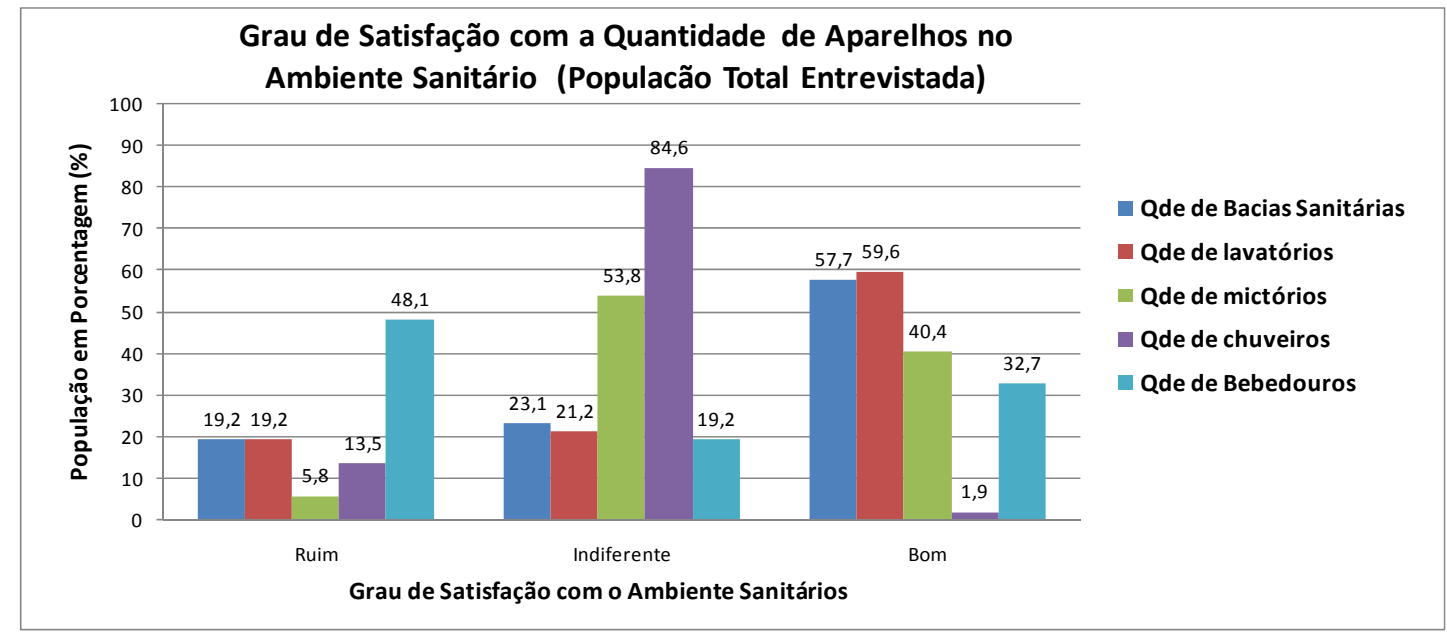

Figura 3: Grau de satisfação com a Quantidade de Aparelhos no Ambiente Sanitário.

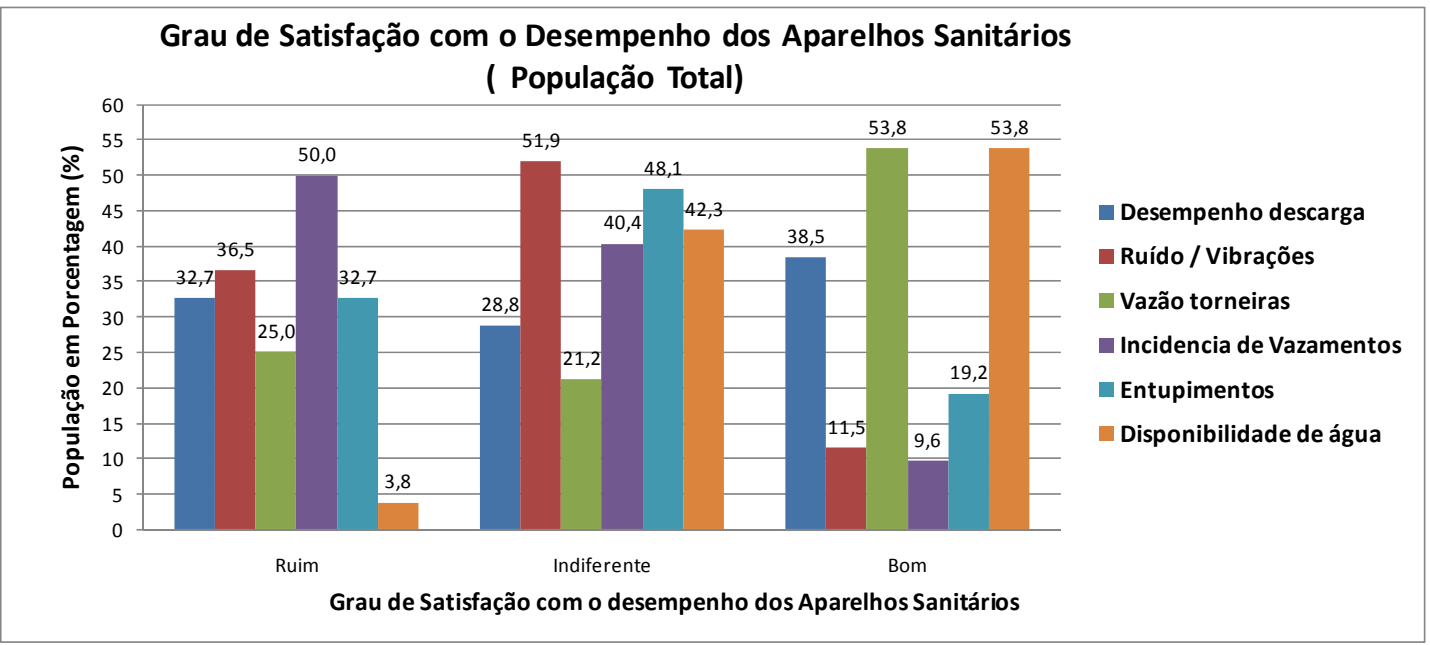

Figura 4: Grau de Satisfação com o Desempenho dos Aparelhos Sanitários.

$\mathrm{Na}$ avaliação dos bebedouros, ilustrado pelo gráfico da Figura 5, foi detectada elevado índice de insatisfação com relação à quantidade de bebedouros $(55,8 \%)$ e higiene $(40,4 \%)$. A maioria dos usuários é indiferente a vazamentos (63,5\%). A vazão da água foi, de maneira geral, considerada boa. Em uma visão geral, o grau de satisfação dos usuários relatou-se como indiferente ao desempenho deste aparelho. Além disso, outras patologias foram instigadas à percepção, utilização e conforto do usuário. As interrupções por falha de funcionamento de banheiros e bebedouros se mostraram pouco frequentes, de acordo com opinião de $55 \%$ dos entrevistados. Os entrevistados em maioria, $63,7 \%$, não se atentaram às questões relacionadas a vazamentos. Dos que observaram vazamentos, conforme mostrado no gráfico da Figura 7, 32,7\%, 58,8\% relataram uma média frequência na ocorrência de pontos de infiltração. $23,5 \%$ relataram baixa frequência, $11,8 \%$ alta frequência e o restante não se recordava da frequência, conforme mostra o gráfico da Figura 6.

Finalizando os dados coletados pelos questionários, no desempenho dos sistemas de água pluvial, a maioria dos colaboradores $(51,9 \%)$ disseram perceber empoçamento no piso e, também em maioria (78,8\%), disseram não observar transbordamento de calhas, gotejamento e ineficiência no sistema de drenagem. 
Por fim é importante ressaltar as opiniões dos funcionários do DAC, que possuem uma rotina diferente dos demais usuários. As funcionárias entrevistadas, utilizam um banheiro interno de uso exclusivo de funcionárias o qual possui difícil acesso, por possuir entrada do outro lado, agrega do um grande percurso. Desta forma, por se tratar de outro público e outro ambiente sanitário para a população feminina, as análises feitas foram tratadas separadamente.

A maioria dos colaboradores da DAC utilizam, cinco dias na semana, o lavatório e a bacia utilizam, cinco dias na semana, o lavatório e a bacia sanitária. Já o bebedouro público é um aparelho pouco utilizado por este público, que prefere levar água mineral. Embora $100 \%$ dos entrevistados indicar que a quantidade de sanitários é suficiente, $66,7 \%$ indicou que o banheiro é muito distante. A maioria alegou estar satisfeito com o ambiente sanitário e com seu desempenho, assim como em relação com a quantidade de aparelhos no atendimento a demanda, com ressalva do bebedouro que empatou em números nos três status de comparação: ruim, indiferente e bom.

Com relação ao desempenho dos aparelhos sanitários o dado que ressaltou foi que a maioria dos funcionários entrevistados detectou a presença de vazamentos. Os bebedouros apresentaram $100 \%$ de aprovação nos quesitos levantados de desempenho: higiene, conforto, vazão, quantidade e vazamentos. As falhas e interdições nos banheiros e bebedouros foram classificados como pouco frequentes para $66,7 \%$ das pessoas, sendo que $33,3 \%$, indicou alta frequência. Não foram relatados problemas relacionados a infiltração por nenhum dos colaboradores e a maioria detectou problemas relacionados a gotejamento relacionado com o sistema de água pluvial da edificação.

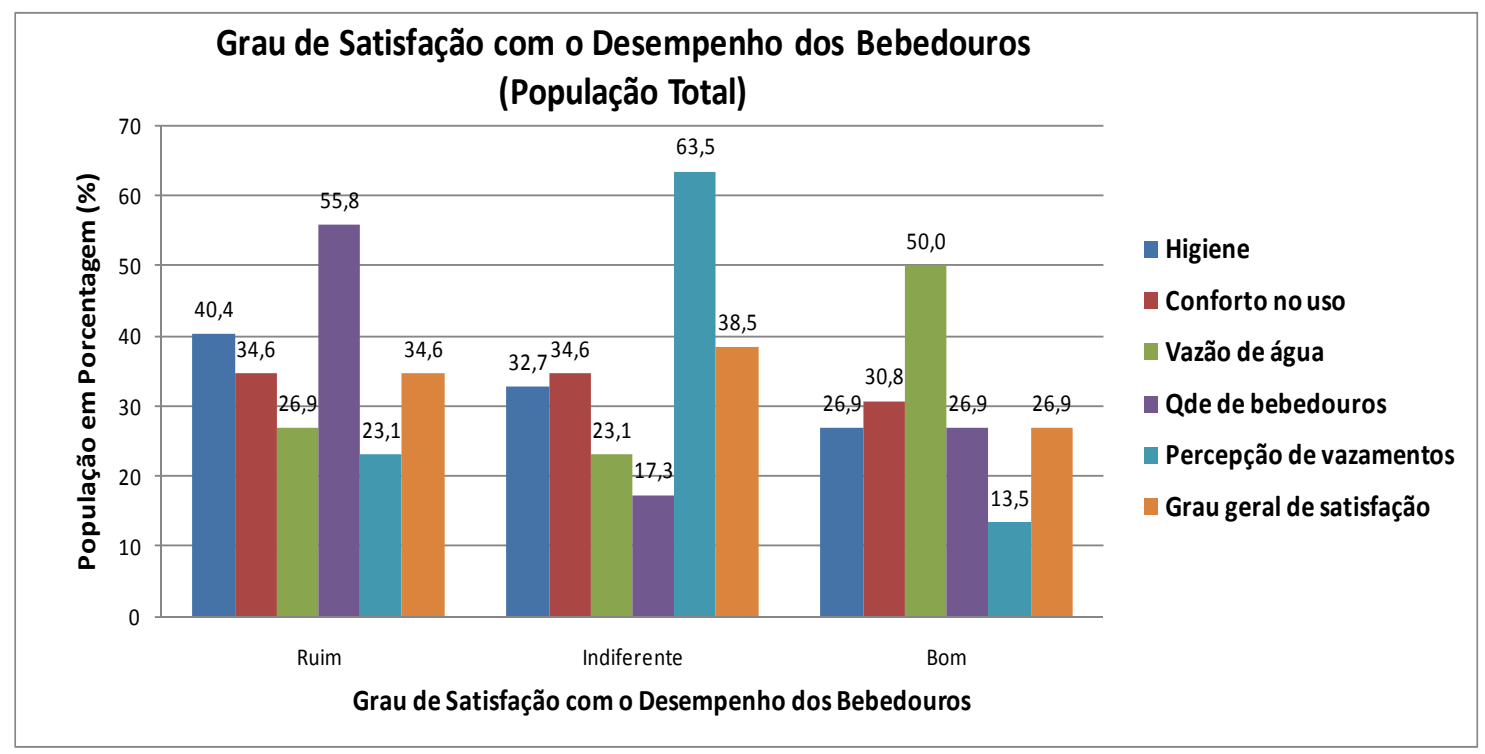

Figura 5: Grau de satisfação com o Desempenho dos Bebedouros.

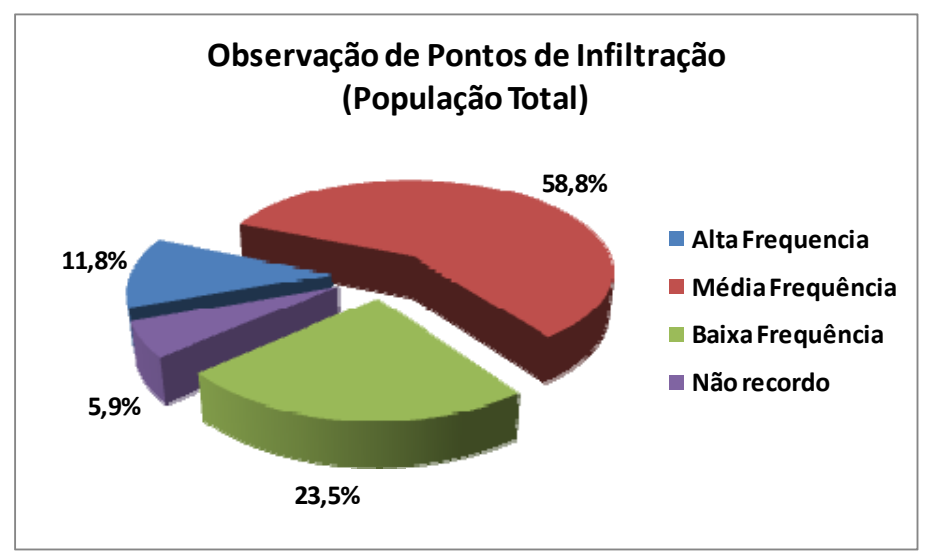

Figura 6: Observação de Pontos de Infiltração. 


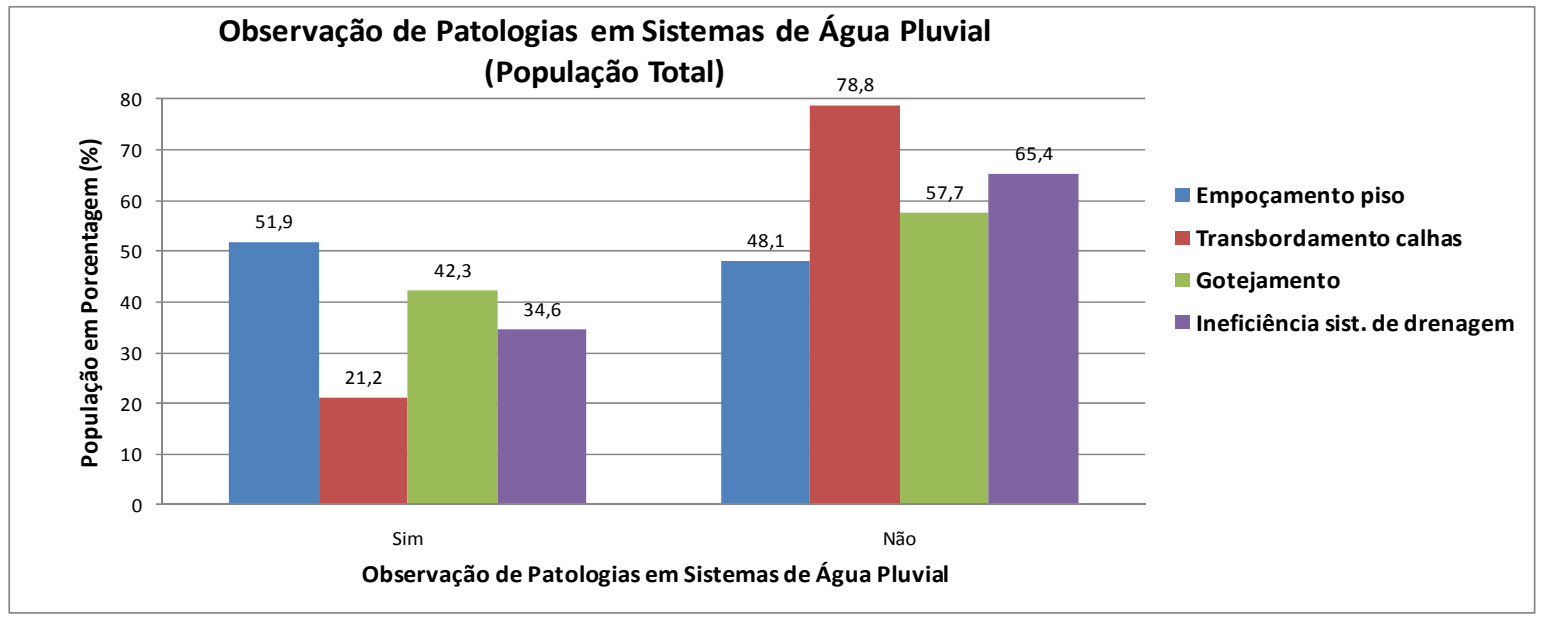

Figura 7: Observação de Pontos de Infiltração

\subsection{Levantamento técnico}

Seguindo a metodologia citada, para estabelecer uma análise entre a percepção do usuário e a situação técnica atual dos SPHS do edifício do Ciclo Básico II, além da aplicação dos questionários foi realizada uma vistoria técnica no sistema e gerado um diagnóstico, onde houve registro iconográfico de patologias e não conformidades normativas. Desta maneira, nesta etapa foram verificados os componentes dos sistemas de água e esgoto, além do sistema de captação de água pluvial da edificação.

O edifício é constituído por três pavimentos conforme ilustra as Figuras 8 e 9 . Ele abriga a Diretoria Acadêmica da Unicamp (DAC), localizada no pavimento térreo e salas de aula e auditórios no primeiro e segundo andar. Todos os pavimentos possuem banheiros públicos, femininos e masculinos acessíveis apenas no lado esquerdo de quem entra no prédio. Os banheiros femininos posicionados do lado direito de ambos os pavimentos funcionam como depósito de materiais de limpeza, enquanto que os banheiros masculinos só são abertos em dias de evento no prédio, este desuso teve início devido a atos de vandalismos nestes ambientes.

\subsubsection{Pavimento Térreo}

A avaliação das patologias presentes nos sistemas prediais hidráulicos e sanitários do pavimento térreo concentrou-se principalmente nos sanitários, onde foi verificada uma série de patologias registradas no croqui do ambiente conforme ilustra a Figura 10.

Por meio da avaliação in loco e, registros feitos pelas fotos mostradas no Figura 11, observou-se no banheiro masculino o entupimento de um dos lavatórios devido a pedaços de toalhas de papel jogadas pelos próprios usuários, verificou-se também, o travamento da válvula de descarga de dois mictórios e de uma bacia sanitária. Um dos mictórios também apresentava vazamento de esgoto no sifão. Ainda no banheiro masculino, foi possível observar a falta de grelha em uma caixa sifonada que encontrava entupida

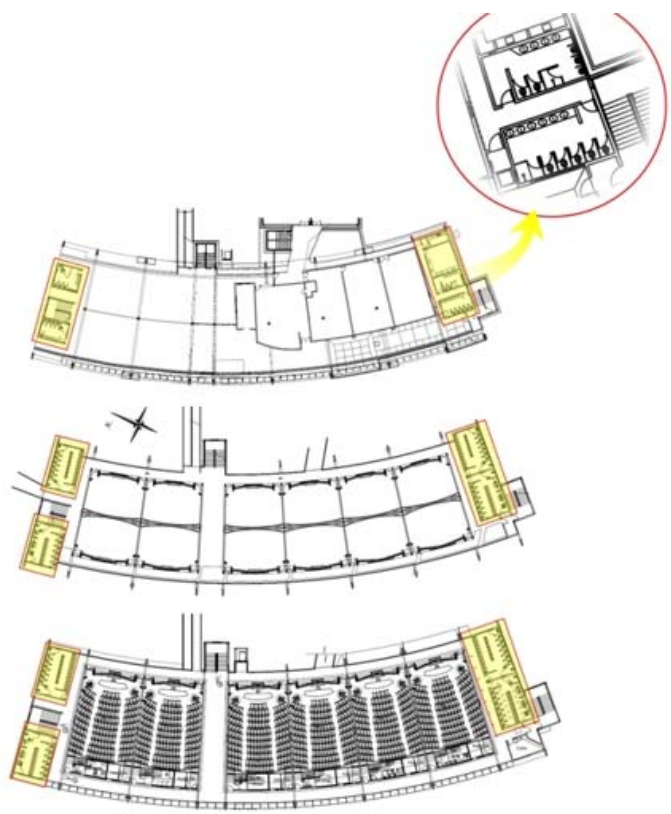

Figura 8: Projetos Ciclo Básico II com destaque dos ambientes sanitários de cada pavimento.

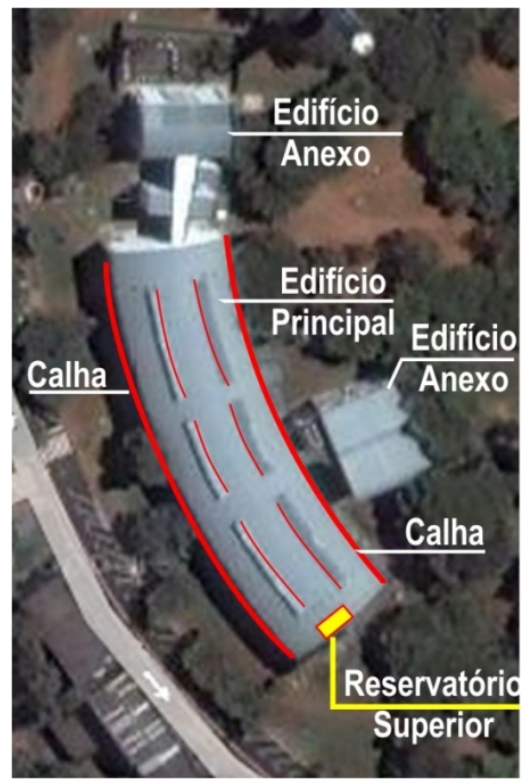

Figura 9: Foto aérea do Ciclo Básico II com destaque do edifício principal, reservatório e calhas. 
devido à deposição de lixo. Por fim o ambiente apresentava diversas louças sanitárias manchadas e papeleiras e portas de cabine danificadas.
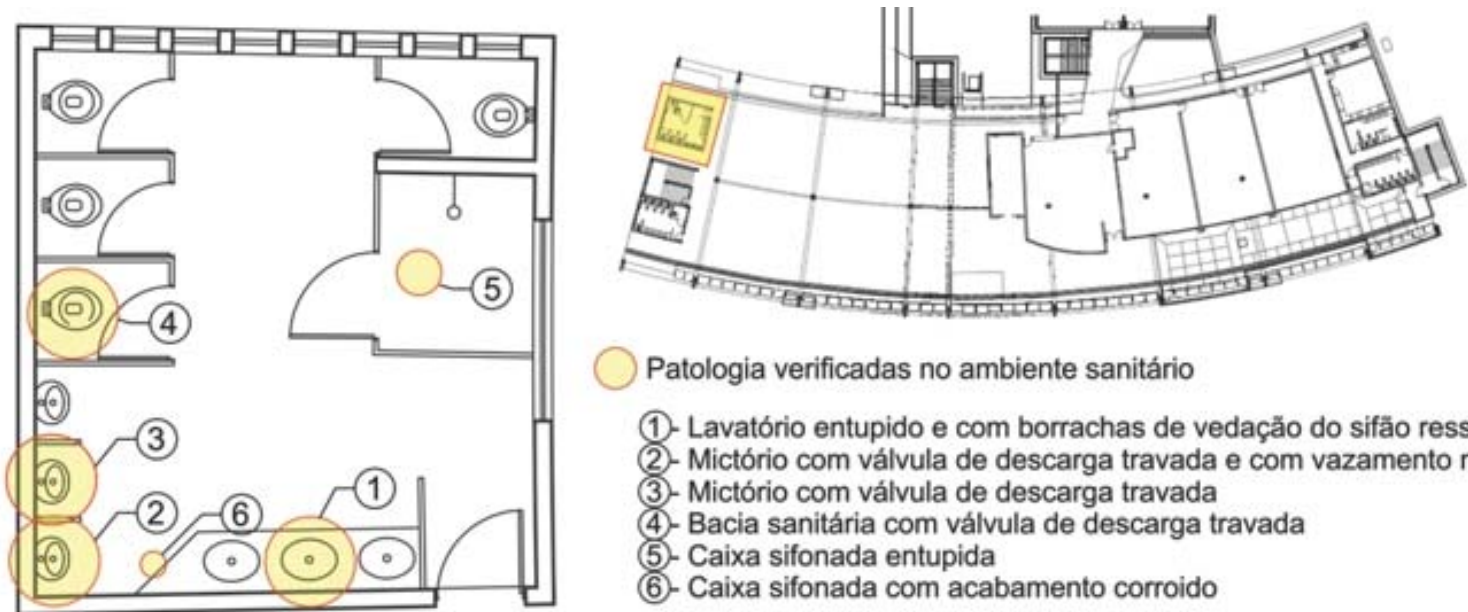

Patologia verificadas no ambiente sanitário

(1) Lavatório entupido e com borrachas de vedação do sifäo ressecadas

(2)- Mictório com válvula de descarga travada e com vazamento no sifão

3.- Mictório com válvula de descarga travada

4) - Bacia sanitária com válvula de descarga travada

(5)- Caixa sifonada entupida

6.- Caixa sifonada com acabamento corroido

Figura 10: Patologias encontradas no banheiro masculino do pavimento térreo do Ciclo Básico II - Unicamp.
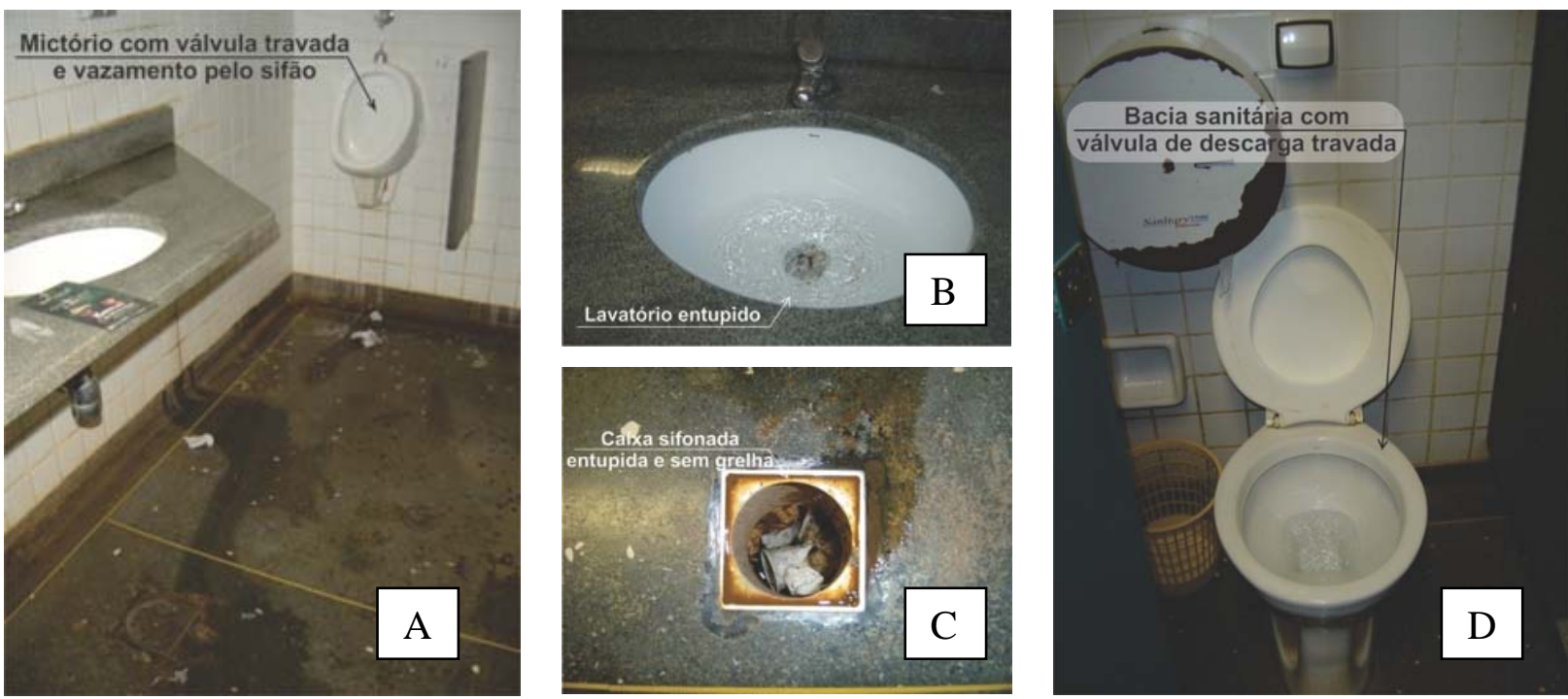

Figura 11: -Patologias encontradas nos componentes do banheiro masculino do pavimento térreo do Ciclo Básico II - Unicamp. A) Vazamento do mictório B) Lavatório entupido C) Caixa sifonada entupida D) Bacia sanitária com válvula de descarga travada.

As instalações sanitárias do banheiro feminino, no pavimento térreo, apresentam um bom estado de conservação, segundo levantamento realizado in loco. Visualmente e funcionalmente nenhum dos aparelhos apresentou problemas ou qualquer patologia relacionada a vazamentos, não funcionamento, vandalismo ou falta de manutenção. Uma única ressalva relativa a esse ambiente cabe a uma desativação da tubulação de distribuição de água para abastecimento de um chuveiro. A cabine relativa ao chuveiro encontrase trancada e desativada, conforme mostra a Figura 12.

A avaliação de patologias nos sistemas prediais hidráulicos sanitários (SPHS) no pavimento térreo, também apontou falhas no sistema de captação e drenagem de águas pluviais. A Figura 13 ilustra a grelha de captação de água de chuva que contorna todo o pavimento térreo. A falta de manutenção e remoção de sedimentos no interior da grelha atrapalha 0 escoamento de água pluvial, podendo proporcionar transbordamento durante eventos de chuva. Registros obtidos por meio dos questionários aplicados aos usuários do local mostram que empoçamento pontuais no piso do pavimento térreo ocorrem com certa frequência durante períodos de chuva. A terra proveniente do talude, também contribui com a deposição de sedimentos dentro da grelha. 


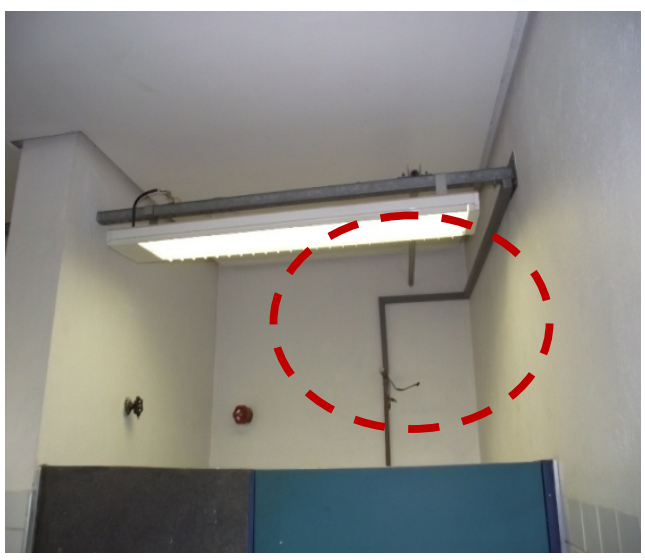

Figura 12: Chuveiro desativado no banheiro feminino.
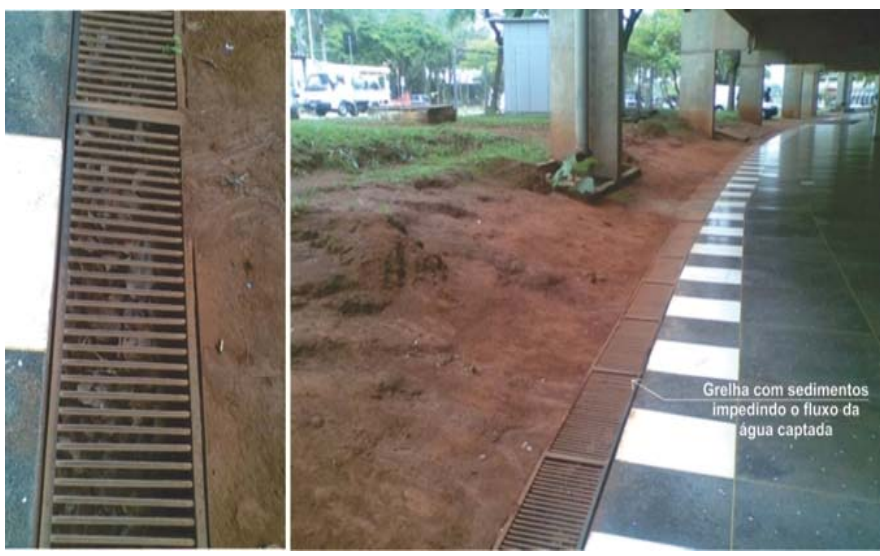

Figura 13: Grelha no pavimento térreo com deposição de sedimentos impedindo o fluxo adequado de água.

A limpeza das calhas também pode ser levantada como um problema. Conforme mostra a Figura 15, após um evento de chuva pode-se observar a quantidade de material proveniente das calhas que depositou nas caixas de pedra onde deságuam os condutores verticais de águas pluviais. de manutenção e limpeza das calhas e grelhas auxiliaria a evitar este tipo de problema. Outro problema observado quanto ao sistema predial de água pluvial é a presença de pontos empoçamento e acúmulo de sedimentos devido à inexistência de sistema de captação de água pluvial, conforme mostra a Figura 14.

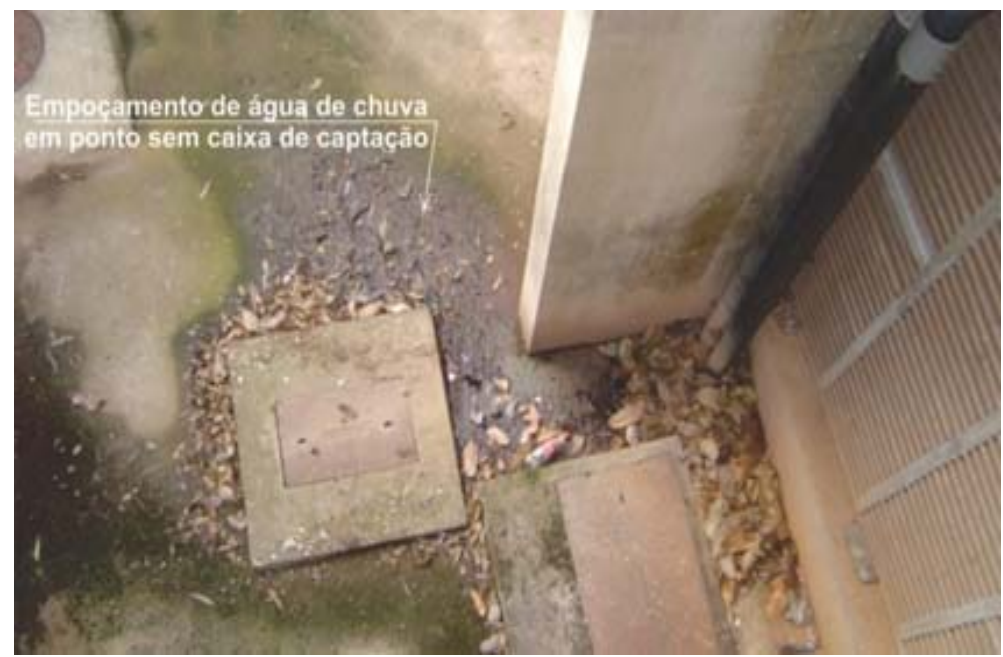

Figura 14: Ponto de empoçamento de água pluvial no pavimento térreo com acumulo de sedimentos devido a inexistência de caixa de captação de água pluvial.

Tubulações de água fria, esgoto e águas pluviais expostas a intempéries também podem ser classificados como patologias de sistemas prediais, pois a maioria dos tubos não possuem proteção contra a incidência de radiação UV.

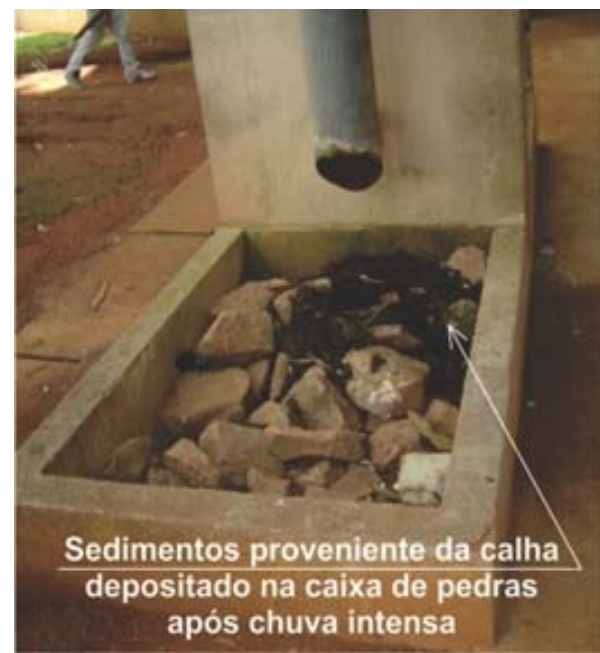

Figura 15: Sedimento proveniente da calha após chuva intensa.
Em curto prazo as tubulações expostas perdem a resistência mecânica podendo apresentar vazamentos com maior facilidade. As Figuras 16 e 17 mostram dois exemplos de tubulações expostas detectadas na edificação avaliada. 


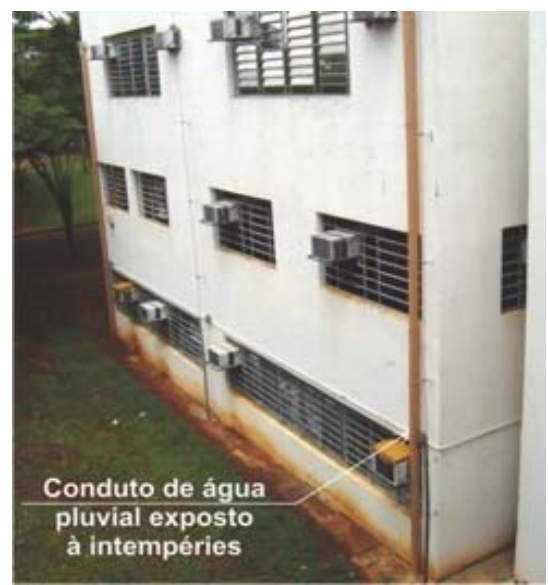

Figura 16: Tubulação de água pluvial exposta à intempéries.

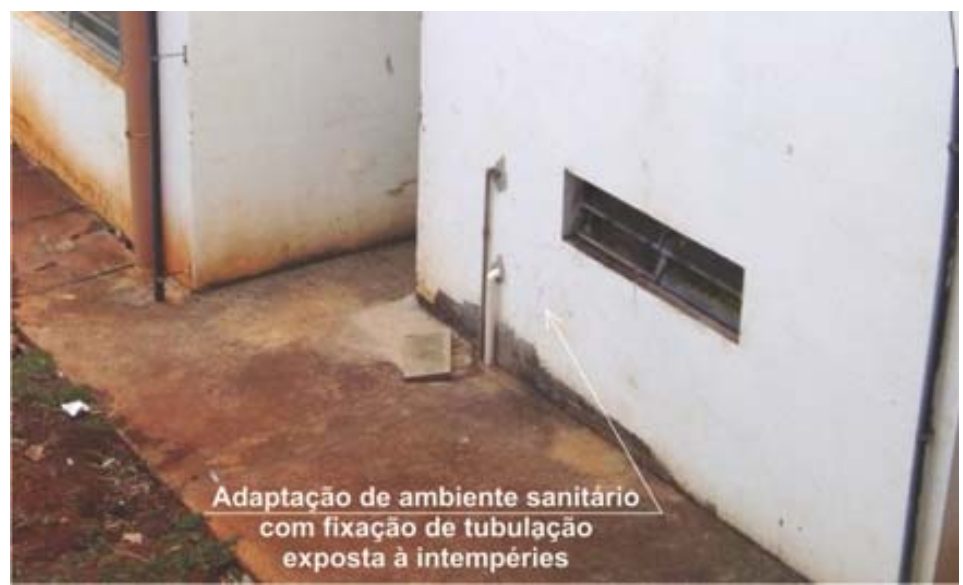

Figura 17: Adaptação de ambiente sanitário com tubulação exposta à intempéries.
Outra patologia observada no pavimento térreo foi o bebedouro, ilustrado pela Figura 18, que apresentava vazamento na calha e no sifão, ocasionando acúmulo de água ao seu redor. A insatisfação com este tipo de bebedouro também foi registrada por usuários que estavam presente no local durante a avaliação do componente.

Por último também observou-se a ocorrência de pontos de gotejamento, como o apresentado pela Figura 19, no acesso à rampa.

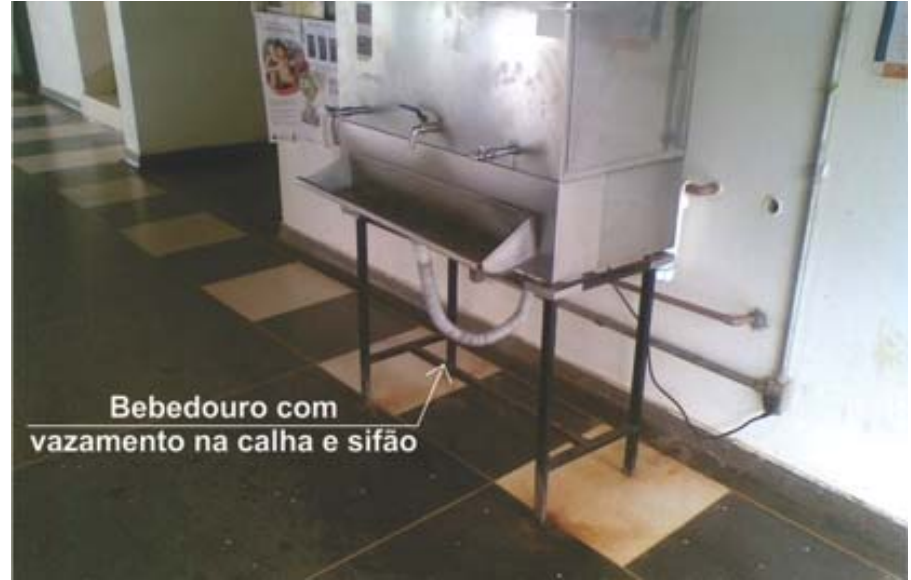

Figura 18: Bebedouro do pavimento térreo com pontos de vazamento na calha e no sifão.

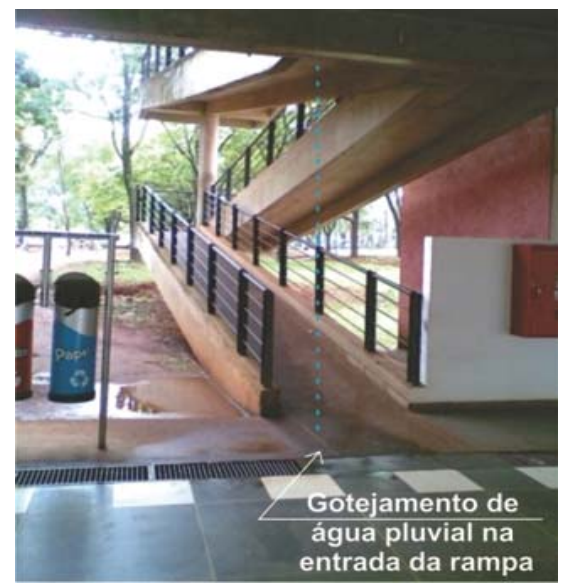

Figura 19: Gotejamento de água pluvial na entrada da rampa.

\subsubsection{Primeiro Pavimento}

Assim como no pavimento térreo, as principais patologias observadas no segundo pavimento apresentavam-se nos banheiros de uso público. Ressalta-se que os banheiros posicionados do lado direito da edificação só são abertos durante eventos e, que o banheiro feminino deste lado foi transformado em depósito de materiais de limpeza.

No Banheiro masculino observou-se diversas manifestações patológicas que foram registradas no croqui do ambiente conforme mostra a Figura 20.

A patologia mais grave encontrada neste pavimento pode ser observada por meio da Figura 21 e, refere-se aos vazamentos constantes de água devido à falha na vedação de três bacias sanitárias do banheiro masculino.

Ainda no banheiro masculino, a Figura 22 apresenta um mictório que possui vazamento do sifão que interliga o aparelho à tubulação de esgoto. Segundo os responsáveis pela manutenção do edifício, o vandalismo é bastante frequente nos banheiros da edificação. Ações como o roubo de grelha dos ralos e das caixas sifonadas e dos acabamentos das válvulas de descarga e registros acabam ocorrendo com maior rapidez que a capacidade de reposição. Assim como apresenta a Figura 23, nos banheiros masculinos existem várias cabines de bacia sanitária que não possuem canopla de acabamento nas válvulas de descarga. A maioria dos ralos e caixas sifonadas também encontram-se sem grelha. 

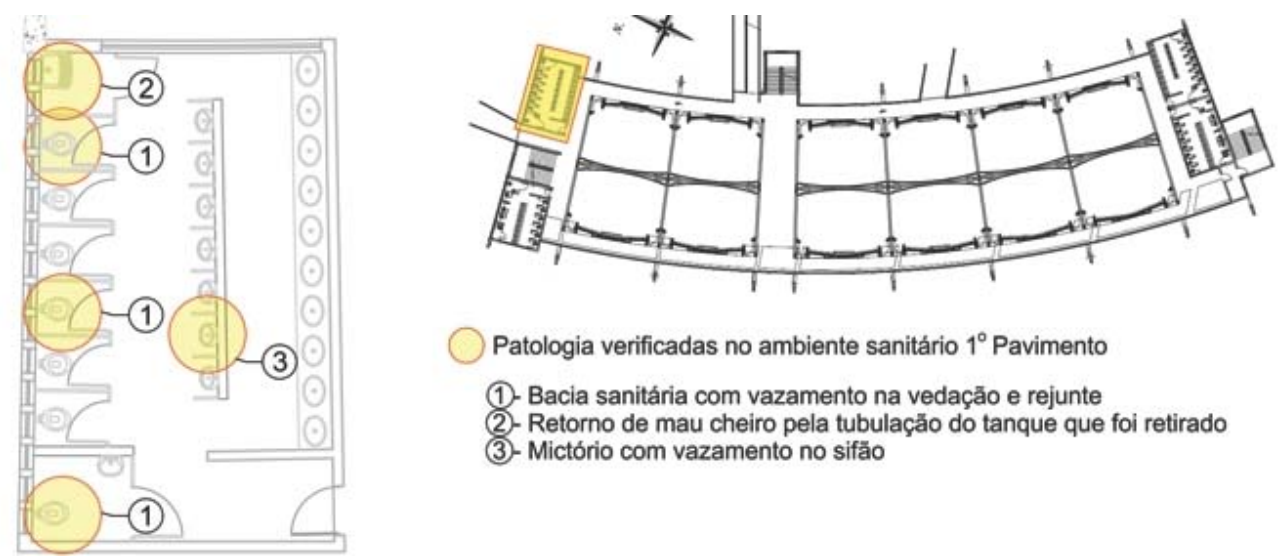

Patologia verificadas no ambiente sanitário $1^{\circ}$ Pavimento

(1)- Bacia sanitária com vazamento na vedaçăo e rejunte

(2)- Retorno de mau cheiro pela tubulaçăo do tanque que foi retirado

(3)- Mictório com vazamento no sifăo

Figura 20: Patologias encontradas no banheiro masculino do primeiro pavimento do Ciclo Básico II - Unicamp.

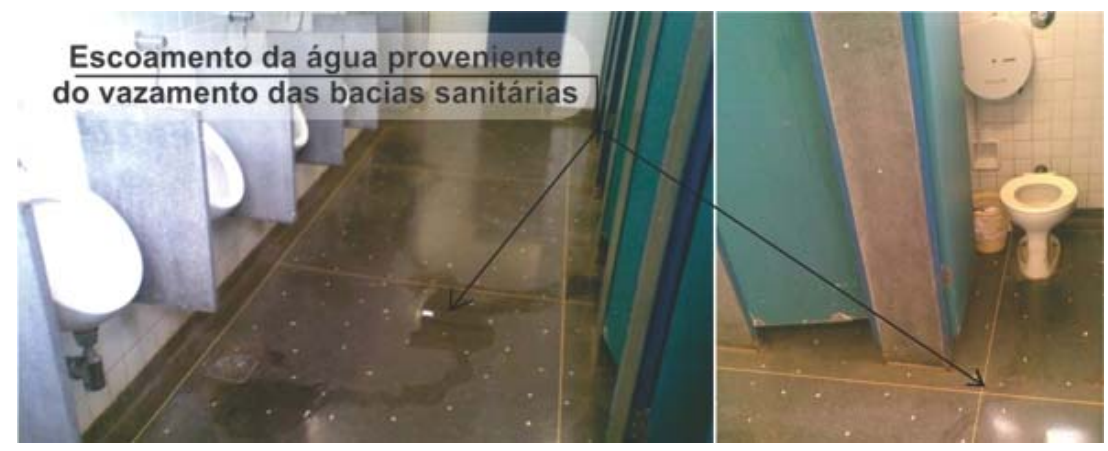

Figura 21: Vazamento na vedação de três bacias sanitárias com escoamento contínuo.

A Figura 24 apresenta a foto do local do tanque posicionado dentro do banheiro masculino do primeiro pavimento. Neste banheiro, o tanque foi removido do local e, devido a não utilização da tubulação de esgoto, uma provável perda do selo hídrico é a causa do retorno de mau cheiro pela tubulação.

Ainda no banheiro masculino, a Figura 22 apresenta um mictório que possui vazamento do sifão que interliga o aparelho à tubulação de esgoto. Segundo os responsáveis pela manutenção do edifício, o vandalismo é bastante frequente nos banheiros da edificação. Ações como o roubo de grelha dos ralos e das caixas sifonadas e dos acabamentos das válvulas de descarga e registros acabam ocorrendo com maior rapidez que a capacidade de reposição.

Assim como apresenta a Figura 23, nos banheiros masculinos existem várias cabines de bacia sanitária que não possuem canopla de acabamento nas válvulas de descarga. A maioria dos ralos e caixas sifonadas também encontram-se sem grelha.

A Figura 24 apresenta a foto do local do tanque posicionado dentro do banheiro masculino do primeiro pavimento. Neste banheiro, o tanque foi removido do local e, devido a não utilização da tubulação de esgoto, uma provável perda do selo hídrico é a causa do retorno de mau cheiro pela tubulação.

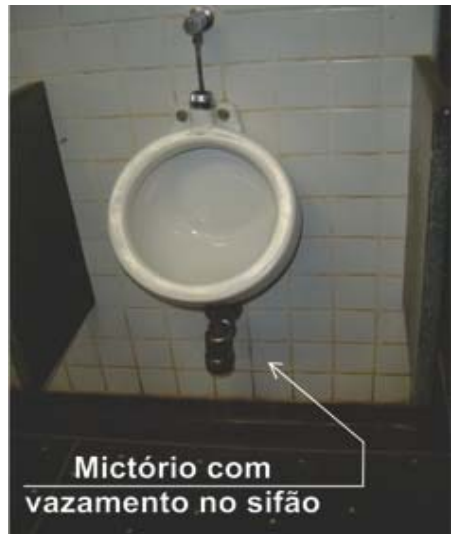

Figura 22: Vazamento no sifão do mictório.

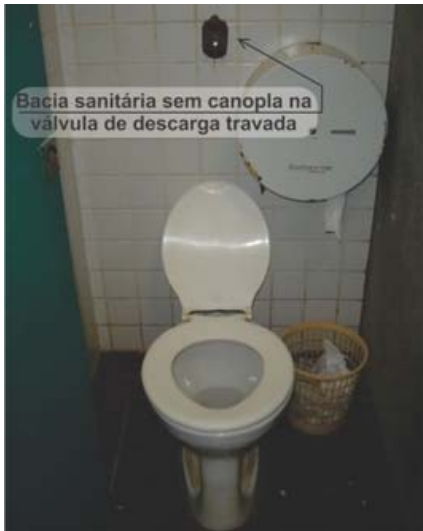

Figura 23: Botão de acionamento da bacia sanitária sem canopla.

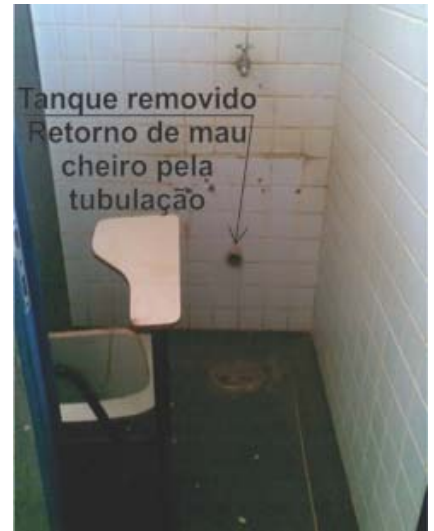

Figura 24: Retorno de mau cheiro pela tubulação de esgoto do tanque. 
No banheiro feminino foram detectados indícios de vazamento em algumas válvulas de descarga, conforme indicado na Figura 25, e provável ponto de infiltração próxima a uma caixa sifonada (Figura 26).
Além dessas patologias, foi verificado também um caminho de água proveniente da cabine onde se localiza o tanque de limpeza, o que pode caracterizar algum tipo de vazamento, não confirmado, por estar inacessível, mas iconograficamente registrado conforme Figura 27.

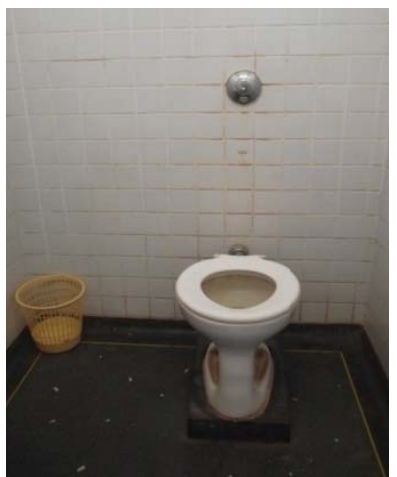

Figura 25: Foto de uma das bacias onde a válvula apresenta vazamento.

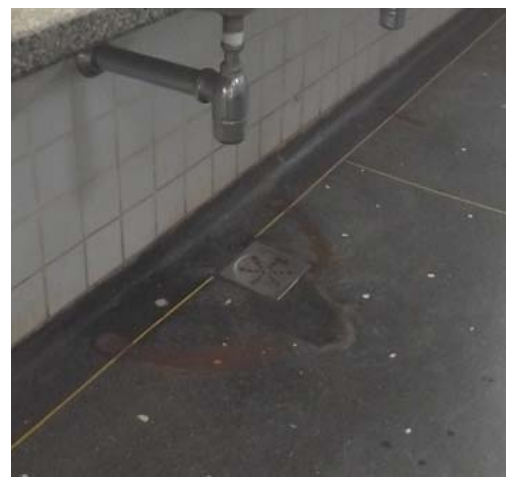

Figura 26: Acúmulo de água, futuro ponto de infiltração próximo à caixa sifonada.

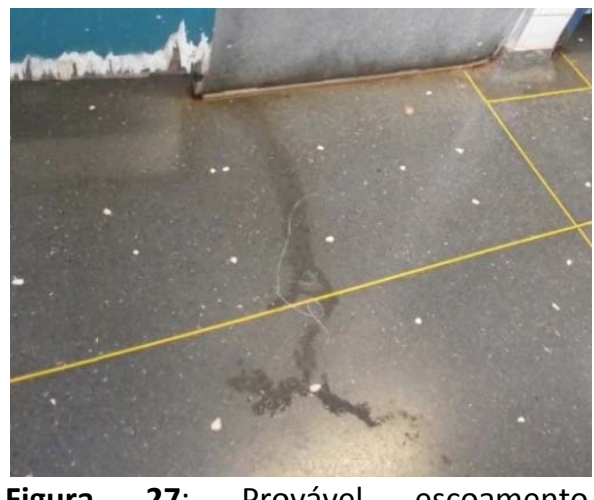

Figura 27: Provável escoamento contínuo proveniente do tanque.
O sistema predial de água pluvial também apresenta alguns problemas neste pavimento. A Figura 28 apresenta uma das canaletas entupidas devido à deposição de sedimentos e falta de manutenção. Durante a ocorrência de chuva pode-se observar que tais pontos demonstram dificuldades na captação e escoamento da água de chuva para os condutos do sistema de água pluvial.
A Figura 29 apresenta a precariedade das instalações dos drenos de ar condicionado que desviam o fluxo de água para uma bica que deságua no pavimento térreo. Os drenos de piso também apresentam uma solução similar e simplesmente desviam o fluxo de água para uma bica que deságua no pavimento térreo. Alguns destes drenos ainda direcionam a água captada para cima de equipamentos de refrigeração do sistema de condicionamento de ar.
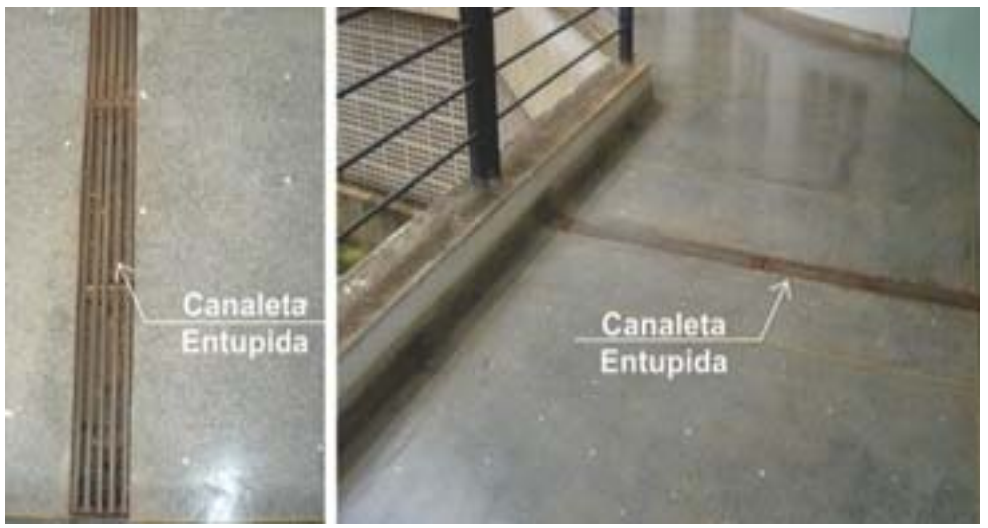

Figura 28: Falta de manutenção da grelha da passarela de interligação com edifício anexo, proporcionando acumulo de água durante e após a ocorrência de chuvas.

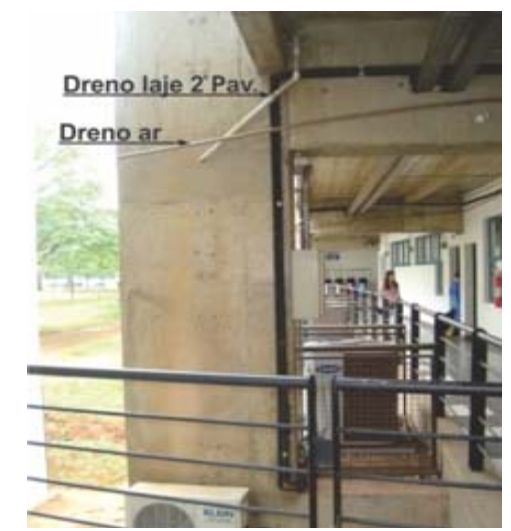

Figura 29: Adaptação precária do dreno do ar condicionado e dreno da laje do pavimento superior.
Outro problema encontrado em todos os pavimentos é a conexão dos engates dos bebedouros com a tubulação de esgoto sem a utilização de adaptador. Este procedimento acarreta em todos os bebedouros escoamento de parte da água descartada para a parede e piso próximo do bebedouro.

Ao observar a laje de cobertura da rampa, identificou-se outra patologia relacionada à declividade do dreno de águas pluviais. Conforme mostra a Figura 30, a tubulação dreno encontrasse inclinada para cima o que ocasiona acumulo de água sobre a laje. A água acumulada promove a manifestação de outras patologias, tais como a lixiviação do concreto e a oxidação da armadura. 


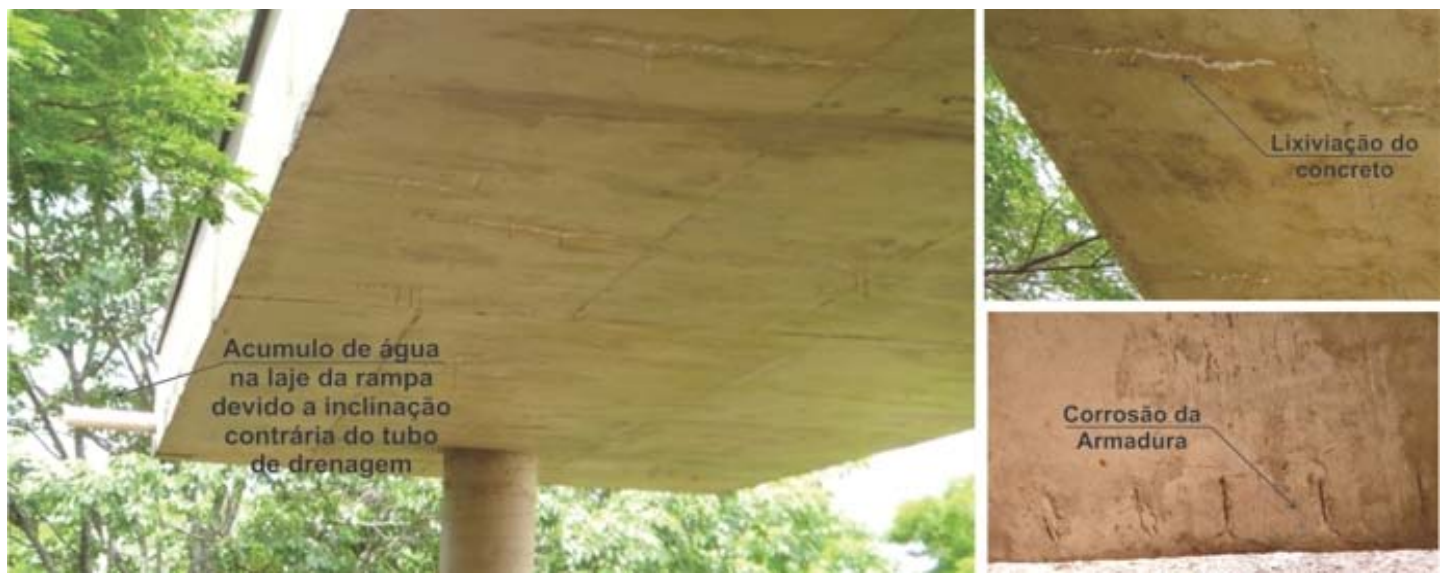

Figura 30: Dreno da laje de cobertura da rampa com declividade invertida proporcionando acumulo de água que contribui para o processo de lixiviação da laje e corrosão da armadura.

Neste pavimento observou-se, também, um ponto de gotejamento no patamar da escada de acesso ao primeiro pavimento, Figura 31 e, o acumulo de água nos ralos utilizados como dreno dos corredores de acesso às salas de aula, Figura 32.

Segundo o responsável pela manutenção do prédio, as grelhas foram roubadas e o sifão do ralo sifonado foi retirado para evitar entupimento. Ressaltase que a adoção de ralo seco seria uma solução de concepção mais apropriada para esta condição, pois evitaria o acumulo de pontos de água e proliferação de insetos.

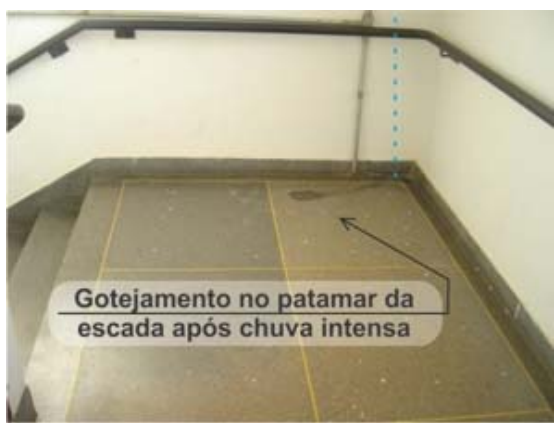

Figura 31: Gotejamento no patamar da escada após chuva intensa.
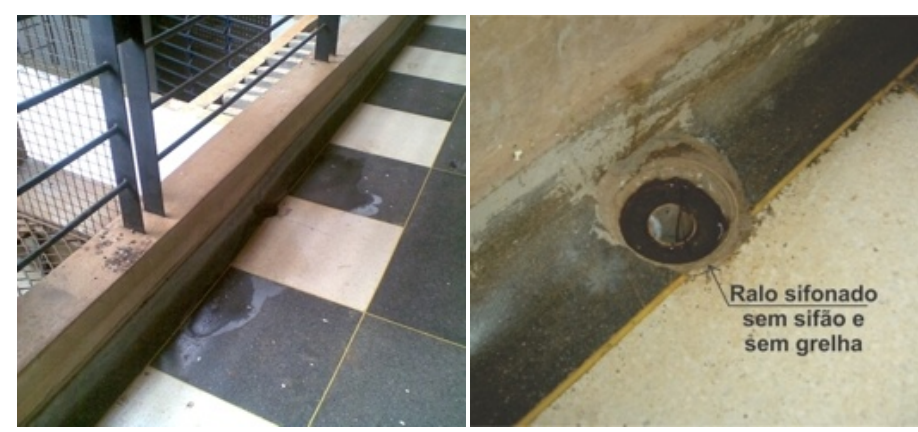

Figura 32: Acumulo de água no ralo sifonado sem grelha e com sifão retirado.

\subsubsection{Segundo Pavimento}

No último pavimento de acesso público, também foram observadas manifestações patológicas similares as que ocorreram no primeiro pavimento.
Com relação aos ambientes sanitários, as patologias foram registradas no croqui de ambiente conforme mostra a Figura 33.
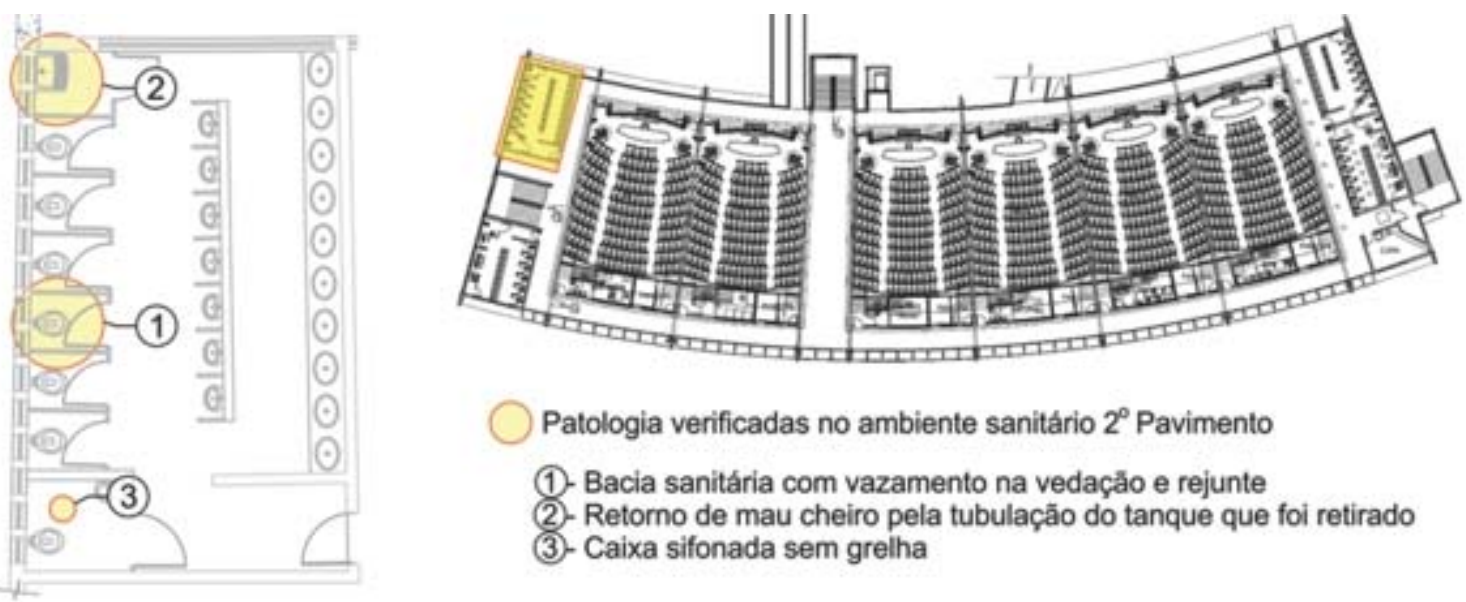

Patologia verificadas no ambiente sanitário $2^{\circ}$ Pavimento

(1)- Bacia sanitária com vazamento na vedaçăo e rejunte

(2)- Retorno de mau cheiro pela tubulação do tanque que foi retirado

(3)- Caixa sifonada sem grelha

Figura 33: Patologias encontradas no banheiro masculino do segundo pavimento do Ciclo Básico II - Unicamp. 
Assim como observado no primeiro pavimento, o banheiro masculino também apresenta pontos de vazamento na vedação das bacias sanitárias e retorno de mau cheiro pela tubulação do tanque. A Figura 34 mostra a água que escoa no piso do banheiro devido ao vazamento das bacias sanitárias.
A Figura 35 mostra uma foto tirada de cima de uma das cabines interditadas devido ao problema citado. A Figura 36 ilustra um mictório com problema de vedação na válvula de descarga o que ocasiona o escoamento contínuo de um filete de água.

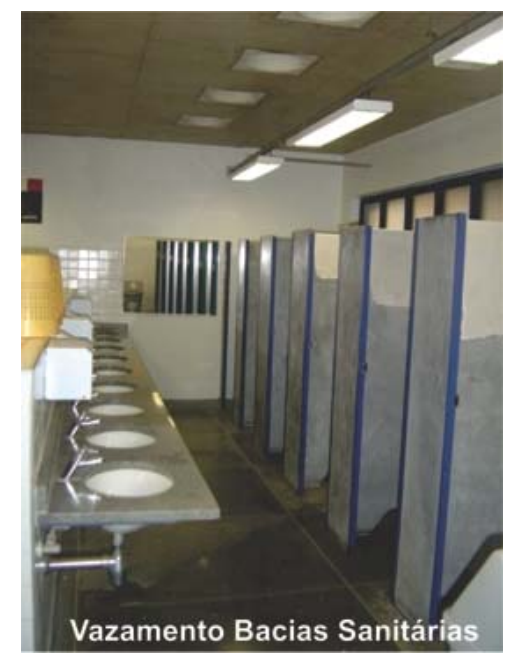

Figura 34: Escoamento de água no piso devido ao vazamento na vedação da bacia sanitária.

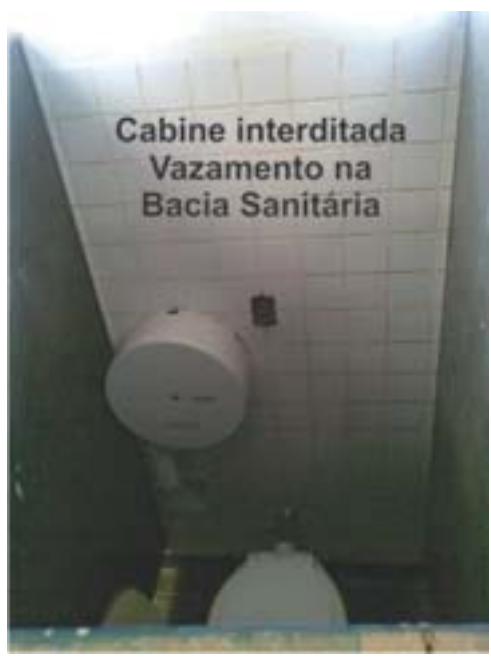

Figura 35: Cabine interditada devido ao vazamento na vedação da bacia sanitária.

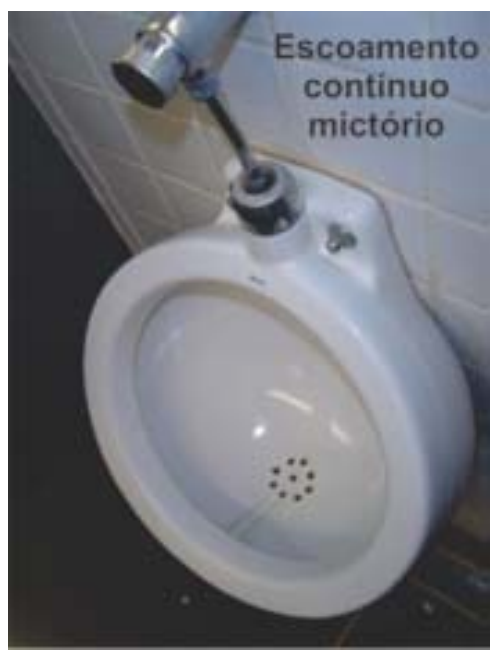

Figura 36: Mictório com vazamento e escoamento contínuo de água.
A Figura 37 mostra a condição de abandono de um dos tanques situados no banheiro masculino. A falta de uso deste componente proporciona a perda do fecho hídrico por evaporação e consequentemente $o$ retorno de mau cheiro proveniente da tubulação de esgoto. A torneira deste tanque também apresenta vazamento de água no volante de abertura e fechamento.
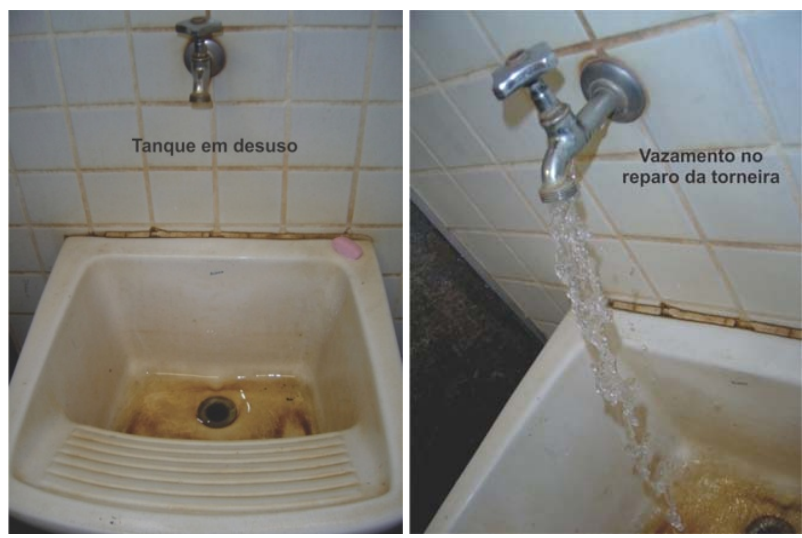

Figura 37: Tanque não utilizado com retorno de mau cheiro pela válvula de esgotamento e vazamento de água no reparo da torneira.

No banheiro feminino deste pavimento também foi verificado vazamentos decorrentes do mal funcionamento e da falta de manutenção nas válvulas de descarga, conforme indica a Figura 39.
A Figura 38, retirada do banheiro masculino que só é aberto durante a ocasião de eventos, apresenta a cabine onde originalmente posicionava o tanque, como deposito de carteiras escolares quebradas. Nesta cabine, assim como no tanque em desuso, verifica-se o retorno de odor pela tubulação de esgoto.

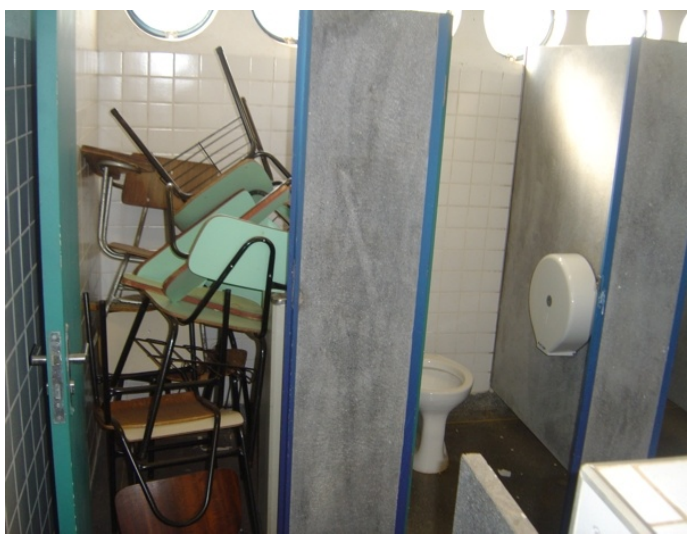

Figura 38: Espaço originalmente destinado ao tanque - retorno de mau cheiro pelo tubo de esgoto devido a perda do selo hídrico.

Outra patologia detectada foi o vazamento na torneira de limpeza situada abaixo da bancada da pia conforme mostra a Figura 40. 


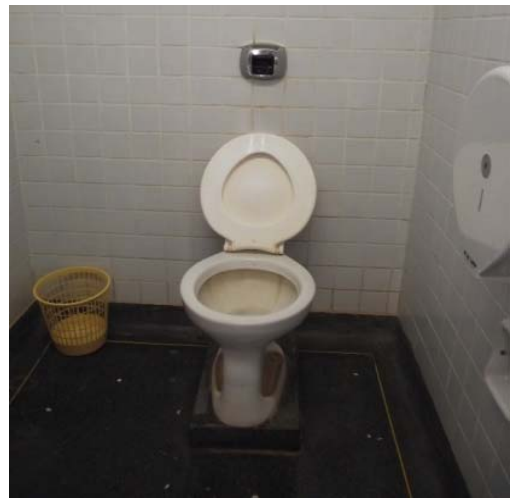

Figura 39: Foto da bacia que apresenta problemas de vazamento na válvula de descarga.

Nos banheiros de livre acesso ao público a maioria dos ralos e caixas sifonadas encontram-se sem a grelha, Figura 41. Um dos bebedouros deste pavimento apresenta gotejamento contínuo de água, conforme mostra a Figura 42.

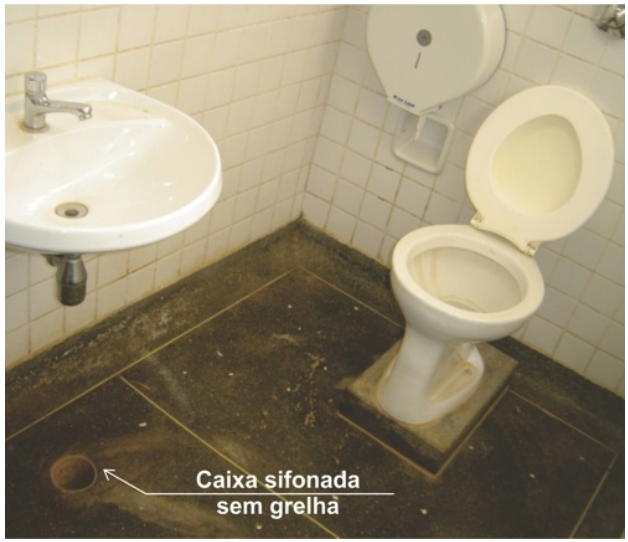

Figura 41: Caixa sifonada sem grelha.

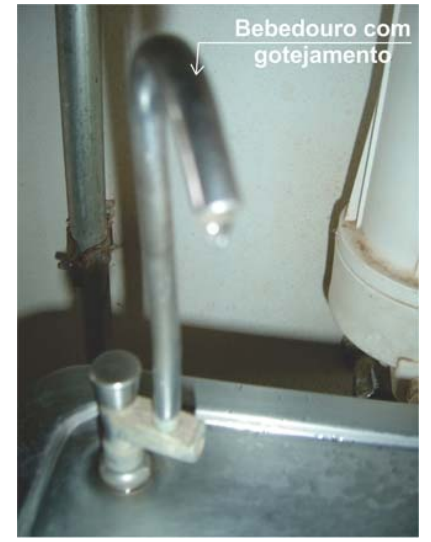

Figura 42: Gotejamento contínuo de um dos bebedouros do pavimento.

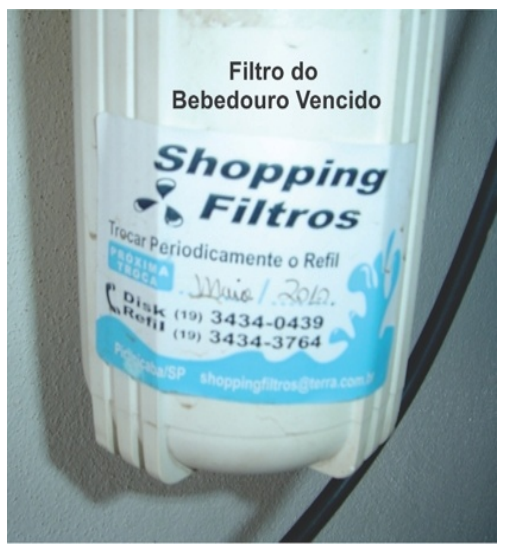

Figura 43: Falta de manutenção do elemento filtrante dos bebedouros.
Outra patologia identificada neste pavimento foi o gotejamento de água sob os dutos de iluminação natural, conforme ilustra a Figura 44. Nos banheiros com acesso restrito aos dias de ocorrência de eventos, a situação mostra-se diferente, com ambientes bem cuidados, conforme pode ser observado pela Figura 45 e, todos os mecanismos funcionando adequadamente, exceto o retorno de odor pela tubulação de esgoto do tanque.

O sistema de combate a incêndio aparentemente apresenta-se em bom estado e com funcionamento adequado. Apesar disto, ressalta-se a falta de sinalização de piso que deve delimitar uma área livre de $1,0 \mathrm{~m}^{2}$ à frente de hidrantes e extintores e, também, a identificação do tipo da carga extintora na sinalização específica de extintores (Figuras 46 e 47).
Em todos os bebedouros do prédio, assim como mostra a Figura 43, o elemento filtrante apresenta-se vencido, ressaltando a necessidade de reposição para garantir a boa qualidade de água dos bebedouros.

Figura 40: Torneira de limpeza apresentando vazamento.

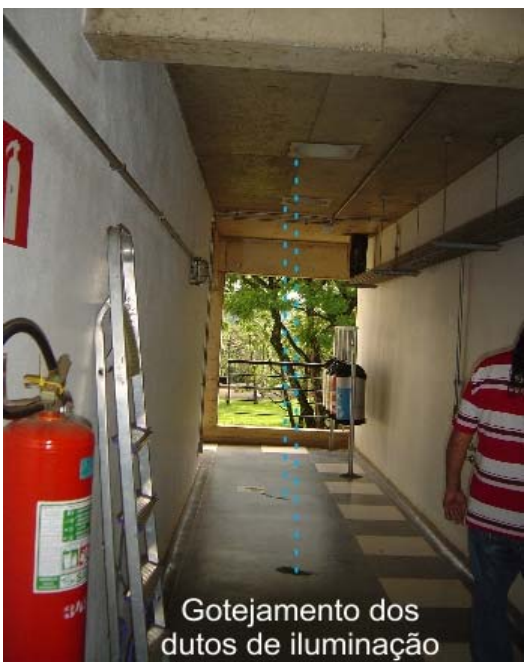

Figura 44: Gotejamento no corredor proveniente dos dutos de iluminação da edificação. 


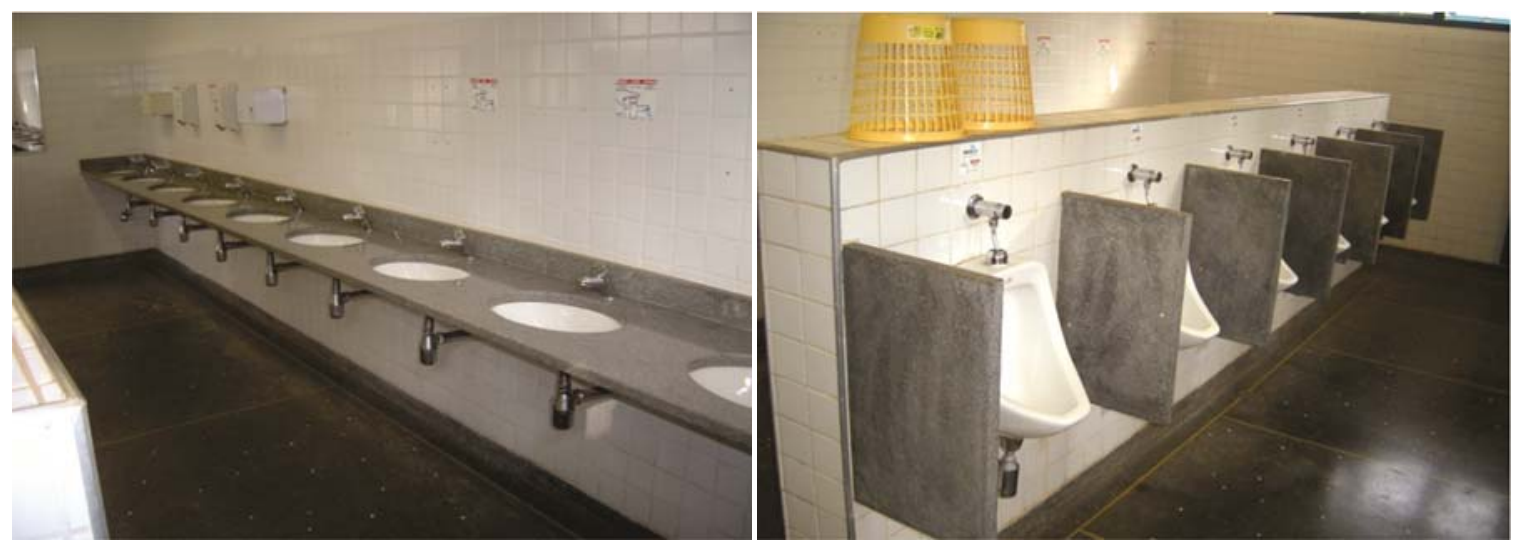

Figura 45: Lavatórios e mictórios do banheiro masculino que só é aberto durante eventos no edifício.

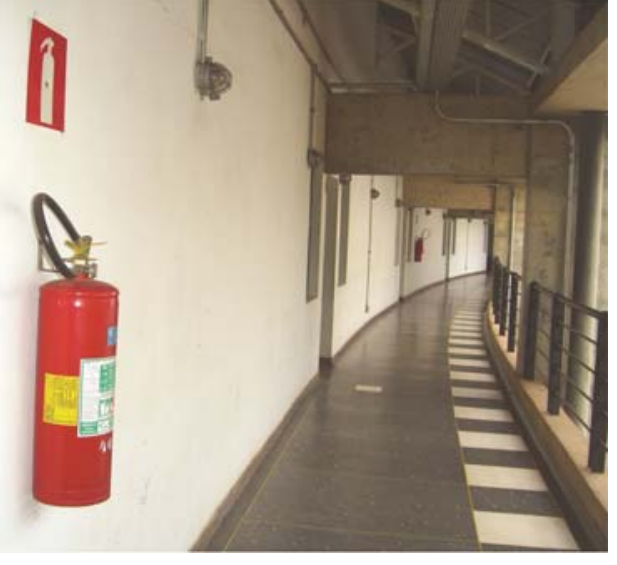

Figura 46: Falta de identificação de tipo de extintor na sinalização e marcação de piso.

\subsubsection{Cobertura}

A Cobertura apresenta-se como o último pavimento avaliado desta edificação quanto aos sistemas prediais hidráulicos e sanitários. A Figura 48 mostra uma foto da cobertura retirada da laje de cobertura do reservatório superior. Nela é possível observar o posicionamento das calhas e dos dutos de iluminação natural.

A Figura 49 mostra o barrilete de distribuição de água com tubulações separadas para alimentação das válvulas de descarga e demais aparelhos sanitários. Apesar da boa condição das instalações, a figura ressalta a necessidade de manutenção do ambiente com a retirada dos ninhos de cupins presentes no local.

A Figura 50 mostra a conexão dos condutos que interligam as calhas aos condutores verticais. Por meio das Figuras, também é possível observar a interligação do ramal de limpeza do reservatório superior na tubulação de água pluvial.

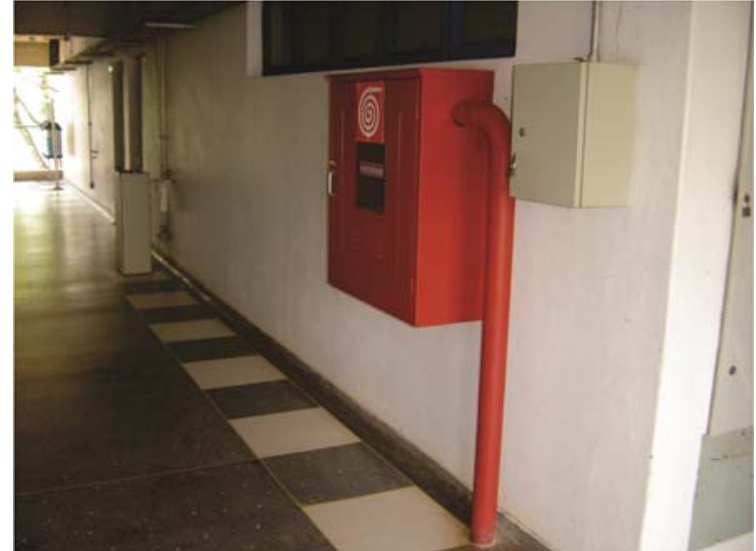

Figura 47: Hidrante falta de sinalização de piso delimitando uma área de $1 \mathrm{~m}^{2}$ livre à frente do abrigo.

Apesar de não apresentar vazamentos, os pontos de interligação destas tubulações podem estabelecer uma situação de fragilidade quanto a estanqueidade do sistema, pois há interconexão de até três materiais diferentes.

Abaixo da cobertura metálica, foram detectados pontos de gotejamento de água, conforme mostra a Figura 51. Os terminais das colunas de ventilação encontram-se posicionados dentro do barrilete, assim como mostra a Figura 52, sendo o correto, prossegui-los para descarga de gases na atmosfera considerando uma distância de $30 \mathrm{~cm}$ acima da cobertura.

Por último, as Figuras 53 e 54 mostram a laje de cobertura do reservatório superior. Nelas é possível observar a necessidade de manutenção da tampa de inspeção do reservatório superior que se encontra em processo de corrosão e, também, proteção do ramal de alimentação do reservatório superior que apresenta-se exposta à intempéries. 


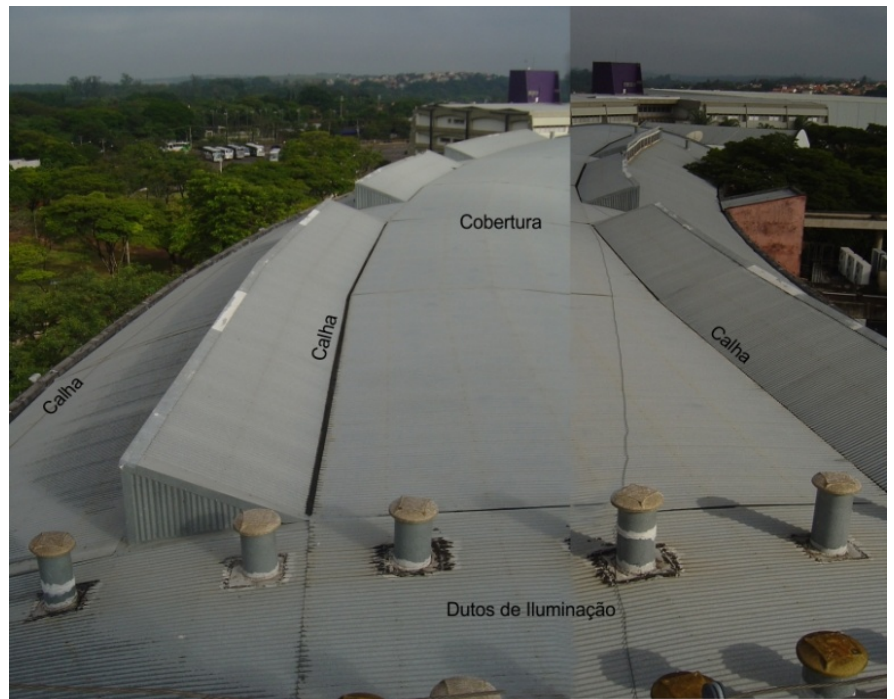

Figura 48: Cobertura observada de cima do reservatório superior do Ciclo Básico II - Unicamp.

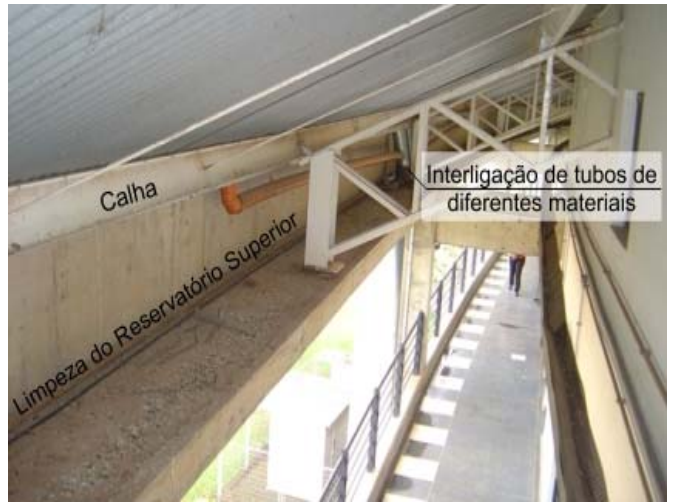

Figura 50: Condutor de água pluvial com interligação de três tubos de materiais e diâmetros diferentes.

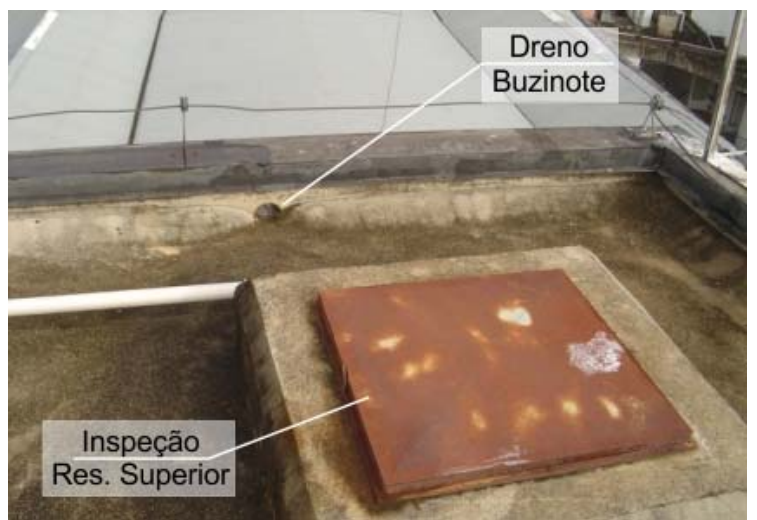

Figura 53: Tampa de inspeção do reservatório superior corroída.

\section{CONCLUSÕES}

Os resultados da aplicação dos questionários em relação à percepção de patologias nos SPHS do prédio do Ciclo Básico II da Unicamp pelos usuários dos respectivos ambientes sanitários, ao serem confrontados com os resultados do levantamento

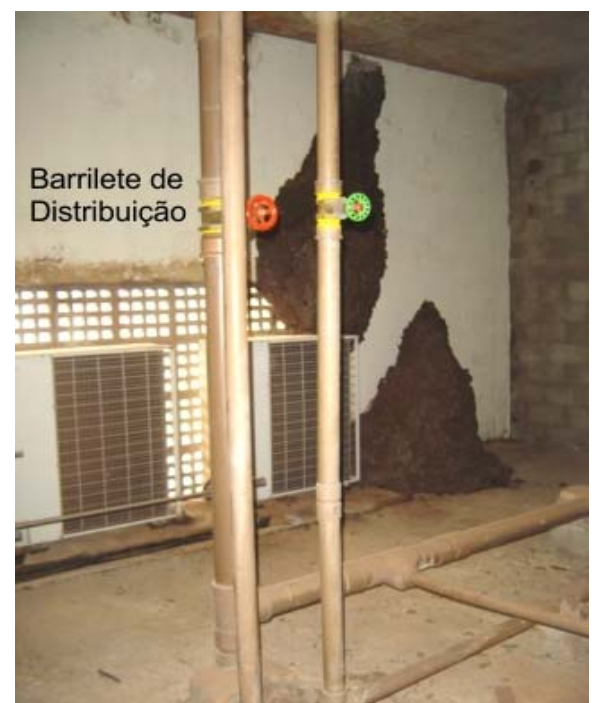

Figura 49: Barrilete de distribuição de água fria.

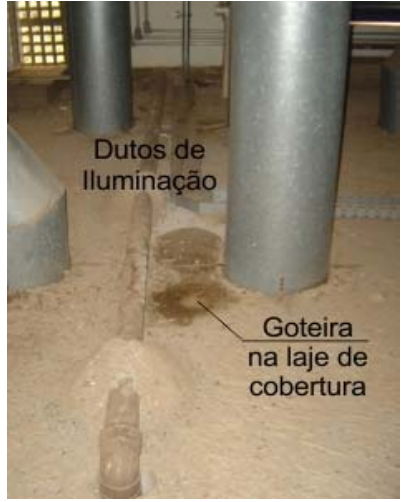

Figura 51: Gotejamento na laje do barrilete.

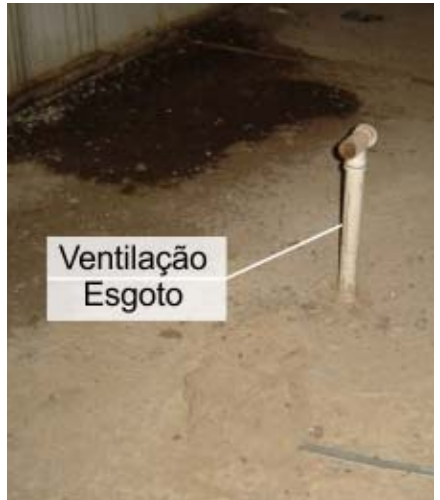

Figura 52: terminal de ventilação sobre a laje de cobertura.

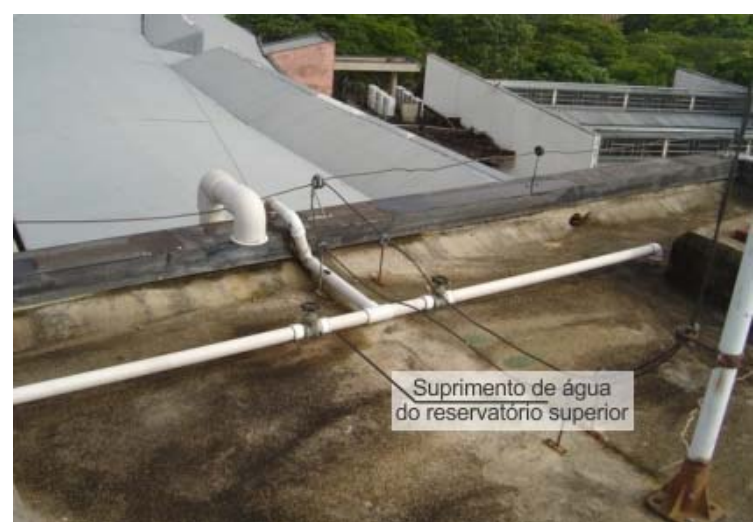

Figura 54: Tubulação de abastecimento do reservatório superior exposta à intempéries.

técnico dessas patologias e não conformidades revelaram um baixo nível de apercebimento dessas patologias. Essencialmente foram relatadas constatações de vazamentos a partir de aparelhos sanitários e de empoçamento de águas pluviais, revelando baixa percepção de mau funcionamento de 
aparelhos sanitários e dos SPHS como um todo, de entupimentos e infiltrações. A insatisfação dos usuários ficou por conta dos aspectos higiene, conforto, odor e projeto.

O acesso, associado às distâncias a percorrer até os ambientes sanitários, foi considerado satisfatório. Os aparelhos sanitários mais utilizados são os bebedouros, cuja quantidade ofertada foi considerada insuficiente.

A baixa percepção de patologias presentes nos SPHS, por parte dos usuários, certamente se deu por diferentes razões. Entre elas, estima-se o reduzido tempo de permanência dos usuários nos ambientes sanitários e o relativo desinteresse na percepção e registro mental das falhas e defeitos nos SPHS, uma vez tratar-se de edifício público. Entretanto, as maiores insatisfações estiveram relacionadas com visíveis falhas de manutenção e conservação, quer nos aparelhos sanitários quer nos ambientes sanitários.

\section{REFERÊNCIAS BIBLIOGRÁFICAS}

AMORIM, S. V. Instalações prediais hidráulico-sanitárias: desempenho e normalização. São Carlos, 1989. 168 p. Dissertação (Mestrado). Escola de Engenharia de São Carlos, Universidade de São Paulo, 1989.

AMORIM, S. V.; VIDOTTI, E.; CASS, A. J. R. Patologias das instalações prediais hidráulico-sanitárias, em edifícios residenciais em altura, na cidade de São Carlos. In: ENCONTRO NACIONAL DE TECNOLOGIA DO AMBIENTE CONSTRUÍDO - ENTAC 93, 1993, São Paulo. Anais... São Paulo: Escola Politécnica da Universidade de São Paulo, 1993. p. 15523.

AMORIM, S. V.; FUGAZZA, A. E. (colaborador). Incidência de falhas em sistemas prediais: estudo de caso. In: CONGRESSO IBEROAMERICANO DE PATOLOGIA DAS CONSTRUÇÕES, IV; CONGRESSO DE CONTROLE DE QUALIDADE, VI, 21-24 out. 1997. Porto Alegre. Anais... 7 p.

AMORIM, S. V.; DIAS JR., R. P.; SOUZA, K. E. Melhoria da qualidade dos sistemas prediais hidráulicos e sanitários através do estudo da incidência de falhas. In: CONFERÊNCIA LATINO-AMERICANA DE CONSTRUÇÃO SUSTENTÁVEL, I / ENCONTRO NACIONAL DE TECNOLOGIA DO AMBIENTE CONSTRUÍDO, X, 18-21 jul. 2004, São Paulo. Anais...,

ASSOCIAÇÃO BRASILEIRA DE NORMAS TÉCNICAS (ABNT). NBR 15575-6: Edifícios habitacionais de até cinco pavimentos Desempenho. Parte 6: Sistemas hidrossanitários. Rio de Janeiro, 2008. 28 p.

BRASIL. Lei 8.078, de 11 de setembro de 1990. Estabelece o Código de Defesa do Consumidor. Diário Oficial da República Federativa do Brasil. Brasília - DF, 11 set. 1990. Seção IV - Das práticas abusivas, artigo 39; artigo 50.

ILHA, M. S. O.Qualidade dos sistemas hidráulicos prediais. São Paulo, 1993. 50 p. Texto Técnico TT/PCC/07. Departamento de Engenharia de Construção Civil, Escola Politécnica da Universidade de São Paulo.
ILHA, M. S. O. A investigação patológica na melhoria dos sistemas prediais hidráulico-sanitários. Hydro, Aranda, São Paulo, a. 30, n. 30, p.60-65, abr. 2009.

INTERNATIONAL ORGANIZATION FOR STANDARDIZATION. ISO 6241: Performance standards in buildings. Principles for their preparation and factor stobe considered. London, 1984.

KOWALTOWSKI, D. C. C. K., CELANI, M. G. C., MOREIRA, D. C., PINA, S. A. M., RUSCHEL, R. C., SILVA, V. G., LABAKI, L. C., PETRECHE, J. R. D. Reflexão sobre metodologias de projeto arquitetônico. Ambiente Construído, Porto Alegre, v. 6, n. 2, p. 7-19, abr./jun. 2006.

ORNSTEIN, S.; ROMÉRO, M. (colaborador). Avaliação PósOcupação (APO) do Ambiente Construído. São Paulo: Studio Nobel, EDUSP, 1992. 223p.THOMAZ, E. Tecnologia, gerenciamento e qualidade na construção. São Paulo: Pini, 2000. 449 p. 


\section{LEVANTAMENTO OPINIÃO DO USUÁRIOS}

\section{Avaliaç̃o Pós Ocupacão de usuários do edifício do Ciclo Básico II - Unicamp}

1) Qual a sua função dentro da edificação do ciclo básico II - UNICAMP?
Função
Estudante $\square$
Funcionário
administrativo
Professor $\square$
$\square$ outro:

2) Com que freqüência semanal você utiliza os aparelhos sanitários dos banheiros do prédio do ciclo básico II ?

\begin{tabular}{|l|l|l|l|l|l|l|}
\hline Bacia Sanitária & $\square$ 0 & $\square$ 1 & $\square$ 2 & $\square$ 3 & $\square$ 4 & $\square$ outro: \\
\hline Lavatório & $\square$ 0 & $\square$ 1 & $\square$ 2 & $\square$ 3 & $\square 4$ & $\square$ outro: \\
\hline Mictório & $\square 0$ & $\square 1$ & $\square 2$ & $\square 3$ & $\square 4$ & $\square$ outro: \\
\hline Chuveiro & $\square 0$ & $\square 1$ & $\square 2$ & $\square 3$ & $\square 4$ & $\square$ outro: \\
\hline Bebedouro & $\square 0$ & $\square 1$ & $\square 2$ & $\square 3$ & $\square 4$ & $\square$ outro: \\
\hline
\end{tabular}

3) Dê sua opinião com relação à localização e a quantidade de banheiros no prédio do CBII:

\begin{tabular}{|l|l|l|l|}
\hline Localização & $\square$ distante & $\square$ indiferente & $\square$ adequada \\
\hline Quantidade & $\square$ insuficiente & $\square$ indiferente & $\square$ adequada \\
\hline
\end{tabular}

4) Em relação aos banheiros como você avalia:

\begin{tabular}{|l|l|l|l|}
\hline Higiene & $\square$ ruim & $\square$ indiferente & $\square$ bom \\
\hline Privacidade & $\square$ ruim & $\square$ indiferente & $\square$ bom \\
\hline Conforto no uso & $\square$ ruim & $\square$ indiferente & $\square$ bom \\
\hline Odor & $\square$ ruim & $\square$ indiferente & $\square$ bom \\
\hline Acesso & $\square$ ruim & $\square$ indiferente & $\square$ bom \\
\hline Qde de bacias sanitárias & $\square$ ruim & $\square$ indiferente & $\square$ bom \\
\hline Qde de lavatórios & $\square$ ruim & $\square$ indiferente & $\square$ bom \\
\hline Qde de mictórios & $\square$ ruim & $\square$ indiferente & $\square$ bom \\
\hline Qde de chuveiros & $\square$ ruim & $\square$ indiferente & $\square$ bom \\
\hline Qde de bebedouros & $\square$ ruim & $\square$ indiferente & $\square$ bom \\
\hline $\begin{array}{l}\text { Grau geral de satisfação no projeto do ambiente } \\
\text { sanitário }\end{array}$ & $\square$ ruim & $\square$ indiferente & $\square$ bom \\
\hline
\end{tabular}

5) Em relação aos aparelhos sanitários como você, usuário, avalia:

\begin{tabular}{|l|l|l|l|}
\hline Desempenho da descarga das bacias sanitárias & $\square$ ruim & $\square$ indiferente & $\square$ bom \\
\hline Ruído/ vibrações & $\square$ ruim & $\square$ indiferente & $\square$ bom \\
\hline Vazão de água em torneiras & $\square$ ruim & $\square$ indiferente & $\square$ bom \\
\hline Incidência de vazamentos & $\square$ ruim & $\square$ indiferente & $\square$ bom \\
\hline Percepção de entupimentos & $\square$ ruim & $\square$ indiferente & $\square$ bom \\
\hline Disponibilidade de água & $\square$ ruim & $\square$ indiferente & $\square$ bom \\
\hline
\end{tabular}


6) Em relação aos bebedouros como você avalia:

\begin{tabular}{|l|l|l|l|}
\hline Higiene & $\square$ ruim & $\square$ indiferente & $\square$ bom \\
\hline Conforto no uso & $\square$ ruim & $\square$ indiferente & $\square$ bom \\
\hline Vazão de água & $\square$ ruim & $\square$ indiferente & $\square$ bom \\
\hline Qde de bebedouros & $\square$ ruim & $\square$ indiferente & $\square$ bom \\
\hline Percepção de vazamentos & $\square$ ruim & $\square$ indiferente & $\square$ bom \\
\hline Grau geral de satisfação & $\square$ ruim & $\square$ indiferente & $\square$ bom \\
\hline
\end{tabular}

7) Em relação a falhas que ocasionaram a interdição/não funcionamento de instalações sanitárias (banheiros e bebedouros) como você avalia:

\begin{tabular}{|l|l|l}
$\square$ muito frequente & $\square$ indiferente & $\square$ pouco frequente
\end{tabular}

8) Você já observou infiltrações que parecem ser ocasionadas por instalações hidráulicas?

$\square$ Sim $\square$ Não

Em caso positivo, com que frequência?

\begin{tabular}{|l|l|l|l|}
\hline$\square$ alta frequência & $\square$ média frequência & $\square$ baixa frequência & $\square$ não me recordo \\
\hline
\end{tabular}

9) Em dias de chuva intensa você observa:

\begin{tabular}{|l|l|l|}
\hline $\begin{array}{l}\text { Problemas na drenagem da água com empoçamento no piso, } \\
\text { nos locais de passagem }\end{array}$ & $\square$ sim & $\square$ não \\
\hline Transbordamento de calhas & $\square$ sim & $\square$ não \\
\hline $\begin{array}{l}\text { Gotejamentos em locais indevidos da construção, onde há } \\
\text { passagem de pessoas }\end{array}$ & $\square$ sim & $\square$ não \\
\hline Ineficiência no sistema de drenagem da água da chuva & $\square$ sim & $\square$ não \\
\hline
\end{tabular}

10) Você acha que poderia ser feita alguma melhoria nos ambientes e instalações hidráulicas sanitárias do prédio Ciclo Básico II? Quais? 